\title{
NATURAL LAW AND NATURAL RIGHTS IN ISLAMIC LAW
}

\author{
Anver M. Emon ${ }^{\dagger}$
}

To even begin suggesting that a natural law tradition exists in Islamic law, one has to overcome the hurdles set by those who avowedly deny that such a tradition exists. Respected Islamicists such as Patricia Crone and the late George Makdisi have stated in no uncertain terms that there is no natural law tradition in Islam. ${ }^{\prime}$ Presumably what they mean by this claim is that there is no "orthodox" tradition whereby premodern Muslims (e.g. ca. ninth-sixteenth century CE) allowed human beings to speak on behalf of the divine without recourse to scripture. Reason does not assume any ontological authority akin to that of scripture that would justify using it as a basis for finding, deternining and constructing obligations that emanate from the divine.

In a sense, they are right. The dominant Positivist ${ }^{2}$ thesis, as expressed in premodern usul al-figh or legal theory, holds that where there is no scripture on a matter, one is left in a state of legal suspension (tawaqquf); there is no epistemically coherent way to determine the divine law on that matter, and consequently no one is in a sufficient epistemic position to attribute to God a ruling of any normative force. ${ }^{3}$ Fundamentally, this position enshrines within Islamic law a strict scriptural positivism. Jurists argued that all determinations of God's law must find expression, either directly or indirectly, from scripture. Extrascriptural indices, whether in the form of rational proofs or references to nature, do not provide a proper basis or foundation for asserting the divine law.

$\dagger$ Assistant Professor, University of Toronto, Faculty of Law. B.A., U. Cal. Berkeley; J.D., UCLA; M.A., University of Texas; L.L.M., Yale Law School. Currently a doctoral candidate at UCLA's history department and Yale Law School, specializing in Islamic legal history.

1. George Makdisi, Ibn 'Aqil: Religion and Culture in Classical Islam 130 (Edinburgh U. Press 1997); Patricia Crone, God's Rule: Government and Islam: Six Centuries of Medieval Islamic Political Thought 263-264 (Colum. U. Press 2004).

2. By "Positivist" I mean those intellectual movements that give primacy to the text, and reject a foundational role for reason in law or theology. Positivists, therefore, would generally hold positions against the speculative rationalist Mu'tazilis. For a study that posits a debate between Positivists and speculative rationalists see George Makdisi, The Rise of Humanism in Classical Islam and the Christian West 4-12 (Edinburgh U. Press 1990).

3. See discussion on this point below. 
But lawyers and judges often face de novo situations where no positivist legislation, scripture, or legal text necessarily provides insight, guidance or precedent for judicial decision. As such, a judge having to decide a case must utilize a degree of discretion in determining the rule of law for a given case. Premodem Muslim jurists of Positivist and Mu'tazilite backgrounds both recognized that jurists must use discretion. But the challenge they faced was in how to justify that resort to discretion.

\section{NATURAL LAW AS A FOUNDATION FOR DISCRETION}

For both groups of jurists, one option was to rely on competing models of naturalism. Mu'tazilite jurists like al-Jassas discussed below certainly argued that reason could provide a sufficient basis for asserting the divine law. But al-Jassas justified his position by situating the use of reason within a natural teleology that tied reason to the divine will through the medium of nature. The power of this position was that a naturalist jurist like al-Jassas could make a claim about the divine law by recourse to extra-scriptural indices, where scripture was otherwise silent.

Positivist jurists responded to Mu'tazilite naturalism in their own way. Certainly they denied that reason can independently arrive at the law of God. But as I will discuss below, a Positivist jurist such as Abu Hamid al-Ghazali (d. 1111) still recognized that at times a jurist must utilize his discretion to arrive at a law of God. Positivist jurists admitted that the Shari'a can address all situations. ${ }^{4}$ This is not to suggest that there is a determinate scriptural answer for every given legal issue, but rather that for Positivists the Shari'a in its totality provides guidance about the spirit of the law that a jurist can rely upon to decide a novel case. To tap into this spirit of the law through the totality of the Shari'a, a jurist like al-Ghazali adopted a softer naturalism whereby he rooted the normative quality of nature in the dictates of scripture. For jurists like al-Ghazali, nature is both an objective basis for rational analysis, and a normative foundation for obligation. Certainly its normativity is scripturally determined; but once normativized, nature becomes the foundation for even Positivist jurists to argue teleologically to the law of God through juristic discretion.

4. See e.g. Abu al-Ma'ali 'Abd al-Malik b. 'Abd Allah b. Yusuf al-Juwayni, al-Burhan fi Usul al-Figh, ed. Salah b. Muhammad 'Awida 2:13 (Dar al-Kutub al-'Ilmiyya 1997). 


\section{NATURAL RightS AND LiMITED DETERMINACY IN DisCRETION}

But more than theorizing about foundations for discretion, premodem Muslim jurists actually seemed to utilize discretion in a way that satisfied their concem to provide limited determinacy and objectivity to their decisions of the law of Shari'a. Specifically, premodern jurists seem to have utilized discretion-based contextsensitive conceptions of the individual and social good to which they gave legal expression in order to create and justify a particular rights distribution scheme with limited determinacy and predictability.

These jurists often posited two sets of rights, the rights of God and the rights of individuals (huquq Allah and huquq al-ibad or al-nas). The rights of God referred to the public interest and welfare, and involved a distribution of rights and duties across society that arguably manifested a commitment to a vision of the social good, however that may be defined. The rights of individuals involved personal, individual rights that jurists believed attached to the individual by virtue of his presumed nature. Often the two sets of rights would overlap or conflict.

As discussed below, jurists had to balance the competing values and interests at stake to determine a rule of law in any given instance. But before they could balance the interests, they first had to give those interests some substance. By reviewing pleading requirements concerning the crime of false accusation of illicit sexual relations, I argue that underlying the juristic determination of pleading rules and distribution of rights were conceptions of the individual and social good that the jurists both contended with and balanced to effectuate the greatest good through the law. This is not to suggest that the jurists were always explicit about what those conceptions were. Rather, what this article shows is that jurists were doing more than simply reading scripture as if its meaning were transparent. It seems that whether they were theorizing about juristic discretion or creating a rights regime under the Shari'a, jurists created, negotiated and ultimately justified a particular rights distribution scheme on the basis of competing foundational conceptions that provided limited determinacy in the light of an active use of juristic discretion.

\section{NATURAL LAW IN ISLAMIC LAW}

The Positivist opposition to natural law and the authority of one to rationally order divine obligations arose amidst a theologically oriented conflict between premodem jurists, some of whom did allow one rationally to ascertain divine obligations where scripture was otherwise 
silent. The story of the natural law tradition in Islamic law is a tale of theological rivalry as well as jurisprudential nuance. It pitted the Mu'tazilite jurist-theologians against Positivist theologian-jurists, many of whom were Ash'arite theologians. These were two premodem theological schools whose disagreements spilled into their jurisprudential debates on legal theory, methodology, and ultimately on what I will call natural law.

The Mu'tazilites are often considered the rationalists in Islam, and advocated a naturalist thesis to ground their use of reason with objectivity and normative authority. The Ash'arites, while not oblivious to rational argument, nevertheless opposed Mu'tazilite naturalism on the grounds that the latter indulged human reason to the detriment of obedience to the divine will. The Ash'arites' position was positivist in the sense that they required one to look to express scriptural text for authority and clarity on divine obligations. This underlying tension between the theological schools is clearly evident in the way their adherents argued about natural law. By natural law, I am focusing on one specific issue of the many that comprise natural law debates. ${ }^{5}$ Specifically, I want to address the role of reason and nature in deternining divine obligation where scripture provides no guidance. Can human reason be a mechanism by which individuals can determine the divine law? If the answer is yes, then what is the foundation for using reason in this fashion? In other words, in the face of scriptural sources like the Qur'an and the hadith of the Prophet, how does reason fit into the ontological and epistemic picture of determining divine obligations?

Mu'tazilite naturalist authors such as the prominent Hanafi jurist Abu Bakr al-Jassas ${ }^{6}$ (d. 370/981) ${ }^{7}$ argued that reason can be a source of divine obligation. The challenge was to provide a foundation for reason that justified one's resort to it. Al-Jassas utilized a natural teleology, based on an objective and normative sense of nature, as the foundation for both universal and circumstantially defined values. Al-Jassas argued that all of creation is created for humanity's benefit. He based this

5. For a discussion of various issues discussed within the field of natural law theory, see Pauline C. Westernan, The Disintegration of Natural Law Theory: Aquinas to Finnis 12 (Brill 1998).

6. For his work of jurisprudence, see Abu Baks Ahmad b. 'Ali al-Jassas, Usul al-Jassas: alFusul fi al-Usul, ed. Muhammad Muhammad Tamir (Dar al-Kutub al-'Ilmiyya 2000).

7. In stating the death date of authors, I rely on both the lslamic and Gregorian dating system. The Islamic calendar started in $622 \mathrm{CE}$ when Muhammad migrated from Mecca to Medina. The reference to the Islamic date is used to illustrate the extent of the elapsed time from the era of the Prophet. 
assertion on a Qur'anic verse which reads: "[God] it is Who created for you all that is in the earth" (alladhi khalaga lakum ma $f i$ al-ard jami'an). ${ }^{8}$ The idea is that God put nature at the disposal of humanity. Consequently, it can be used in any way that benefits people. ${ }^{9}$ Human fulfillment is the telos and purpose of God's creation. But this teleology should not be confused with an ethically bleak utilitarianism. Naturalists like al-Jassas were not interested in the calculus of the greatest good. Rather, they used nature to ground their teleology in what they believed to be an objective creation, which also embodied the normativity of the divine will. They expressed this naturalism by discussing the meaning of concepts such as the good (husn, hasan) and evil (qubh, qabih), and the ruling on an act prior to the existence of revelation (min qabla wurud al-shar').

Some scholars such as Crone have argued that ethical questions about pre-revelation society were really about a hypothetical state prior to the existence of any revelation, a type of state of nature scenario. ${ }^{10}$ Others such as Kevin Reinhart have argued that this hypothetical was an indirect way for jurists to contend with a situation that was too difficult to deal with directly. In other words, they posed a counterfactual, and debated the issue in the abstract. ${ }^{\text {" }}$ However, I suggest that this hypothetical was not a hypothetical at all. Jurists were not trying to avoid a difficult question, or speaking about some fictional state where no revelation exists. They were in fact theorizing the foundation for the use of juristic discretion to address those situations where no scripture addresses a given issue. ${ }^{12}$ Premodem jurists would argue that in such cases, an act unaddressed by scripture can be either presumptively permissible, presumptively prohibited, or in a state of suspension. Mu'tazilite naturalists like al-Jassas argued that all acts in creation are presumptively permissible (ibaha). ${ }^{13}$ He infiused nature with a divine,

8. Qur'an 2:29.

9. Al-Jassas, supra n. 6, at 2:100; Al-Qadi Abu al-Hasan 'Abd al-Jabbar al-Asad'abadi, alTaklif of al-Mughni 27, 30 (Taha Husayn ed., n.p.: n.p. n.d.); Abu al-Husayn Muhammad b. alTayyib al-Basri, al-Mu'tamad fi Usul al-Figh 2:315-316 (Dar al-Kutub al-'Ilniyya n.d.).

1. Crone, supra n. 1, at 263-264.

11. A. Kevin Reinhart, Before Revelation: The Boundaries of Muslim Moral Thought 4.5 (SINY Press 1995).

I2. For instance, the premodem positivist jurist Abu al-Ma'ali al-Juwayni (d. 478/1085) acknowledged that those issues addressed by text (al-mansusat) do not adequately address all possible situations ( $a$-waqa' $i$ ) that could arise. Imam al-Haramayn Abu al-Ma'ali 'Abd al-Malik b. 'Abd Allah b. Yusuf al-Juwayni, al-Burhan fi Usul al-Figh 2:13 (Salah b. Muhammad b. 'A wida ed., Dar al-Kutub al-'Ilmiyya 1997).

13. Notably, the Mu'tazilite jurist Abu al-Husayn al-Basri argued that all acts are presumptively permissible as long as there is no indication or evidence of any evil in the act. AlBasri, supra n. 9, at 2:316. 
purposeful nonnativity, and hence ascribed the legal value of pernissibility to all acts not addressed by scripture. As such, nature becomes both the "is" and the "ought" as al-Jassas fused fact and value to move from the objective reality of nature to a normative assessment reflecting the divine will.

For al-Jassas, acts not addressed by scripture are subject to rational evaluation. ${ }^{14}$ Some acts may embody universal values of obligation and prohibition, whereas others may be contextually defined: as such, their presumptive valuation is one of permissibility, although that may change depending on the circumstances. Concerning universal values, al-Jassas said that where there is no scripture, some acts may be universally obligatory (wajib) and not subject to change. Wajib, as determined by reason, applies to those acts that are universally understood as obligatory, such as having faith in God (iman), thanking one's benefactor (shukr al-mun'im), and pursuing faimess (insaf). ${ }^{15}$ These acts are always obligatory and never change in value. Likewise, matters may be deemed to be universally prohibited. These acts are those that one assesses as universally and unchangeably evil, such as disbelief and oppression. Specifically, al-Jassas stated: "[Among the acts known before revelation] is that which is bad in itself (qabih li nafsihi) and prohibited, and which does not change and alter from its state (halihi)." Concerning acts whose values depend on a more context-sensitive inquiry, al-Jassas held that one may rationally determine these acts to be pernissible, prohibited, or obligatory pursuant to the benefits and harms arising from the acts in question ('ala hasab ma yata'allaqu bi fi'lihi min manafi' al-mukallafin wa madarrihim). ${ }^{17}$

\section{Al-Jassas' Natural Teleology}

Whether one views the state or essential character of an act (nafs, hal), or the benefit and harms that an act poses, at stake in this inquiry is an investigation into an empirical and objective reality. This reality serves as the foundation for al-Jassas' epistemic model. But to move from what is to what ought to be, al-Jassas must invest this reality with normative value. The terms "benefit" and "harm" (manafi', naf", madarr, darr) certainly reflect empirical observations. But I suggest that they also reflect a normative reality, given the naturalist

14. Al-Jassas, supra n. 6, at 2:99-105.

15. Id. at 2:100.

16. Id.

17. Id 
presumption that creation was made for the telos of human fulfillment. Arguably, al-Jassas used these terms as a technical shorthand to reflect the divine intent to satisfy human needs, to infuse nature with normativity, and thereby to assert a natural teleology. In other words, the idea that nature poses a benefit for humanity - a benefit purposefully created by God-reflects not only an empirical reality but also a normative one, given the divine imprint on creation.

For al-Jassas, whatever is not addressed by scripture and is not among the universal values is automatically considered permissible if the act poses a greater benefit than harm (lam yakun fihi darrun aktharu min ma yujtalabu bi filihi min al-naf'). ${ }^{18}$ Pennissibility here is a positive rational assertion of normative value. It is the base value of all acts prior to any further investigation into scripture or circumstance. The presumption of permissibility is the means by which al-Jassas argued for the normative value of an objective nature. This argument was based on al-Jassas' presumption that creation is divinely intended to satisfy the telos of human filfillment. He held that creation could have been created for four possible reasons. First, God may have created nature to benefit no one in particular. But this is a waste and foolhardy ('abath wa safah). ${ }^{19}$ Perhaps God created nature to cause injury and not to benefit anyone (khalaqaha li yadurra biha min ghayr naf') ${ }^{20}$ According to al-Jassas, such a proposition would be presumptively abominable and detestable (ashna' wa aqbah). ${ }^{21}$ Third, God may want nature and all of creation to benefit God. But that is impossible, he wrote, since God is not affected by benefits (manafi') or harms (madarr). ${ }^{22}$ The only possibility left for al-Jassas is that God created nature to benefit humanity (annahu khalagaha li manafi' almukallafin). ${ }^{23}$

Because creation exists for the advantage of humanity, all acts (which are a part of creation) are presumptively beneficial for mankind (makhluqatun li manafi' al-mukallafin). ${ }^{24}$ The term "manafi"' and the general notion of benefit denote both an objective good and a purposeful divine creation for human enjoyment. Benefit, therefore, is not only some purely empirical quality, but also is intended to capture the normativity of the divine will. The idea that God would create creation 
for human benefit speaks to how al-Jassas united both fact and value, thereby making nature an empirical and normative foundation for his theory of discretion and the determination of obligations. In other words, al-Jassas argued against those who held that nature is not dispositive and that one cannot presume nature to be beneficial. For alJassas, his view of nature involved a metaphysical assumption about creation, expressed in the notion of benefit (manafi', intifa), that ultimately was intended to create room for the use of juristic discretion to move from the objective empiricism of reality to a normative assessment of value without engaging in any logical fallacy.

Shihab al-Din al-Qarafi (d. 684/1285), a late and significant Malikite-Ash'arite Positivist jurist, criticized the legacy of Mu'tazilite naturalist scholarship, like that of al-Jassas, which considered reason to be a basis for establishing obligation. But in doing so, he also censured his Ash'arite brethren for unfairly characterizing the naturalist position. As will be seen below, many Positivist authors assumed that the Mu'tazilites based obligation on 'aql (reason); it is as if the Mu'tazilites said that reason alone can establish obligation without any reference or regard to the divine. But al-Qarafi was quick to point out that this is not an adequate representation of the Mu'tazilite view. ${ }^{25}$ Mu'tazilite naturalists did not simply state that one's reason alone obligates and prohibits. Rather, according to al-Qarafi, the Mu'tazilites empowered reason in a way that presupposed a certain theology of God that the Positivists such as the Ash'arites denied. Mu'tazilites and Positivists both accepted that obligation comes from God. But Mu'tazilites went one step farther and asserted that God, through His clear wisdom, obligates people to avoid corruption and to achieve benefits. ${ }^{26}$ Importantly, corruption and benefit are qualities subject to rational analysis.

The fundamental debate between the Mu'tazilites and Positivists, according to al-Qarafi, was whether reason can make the move from empirically assessing a beneficial or harmful act to asserting that God has in fact established a specific obligation or prohibition. According to al-Qarafi, the naturalist Mu'tazilites argued that the ability of one to know the substance of God's obligations and prohibitions by reference to benefits and corruption is of the same nature as believing the theological maxim that God is knowledgeable, powerful, and perfect. In

25. Shihab al-Din Abu al-'Abbas Ahmad b. Idris 'Abd al-Rahman al-Sanhaji al-Carafi, Nafa' is al-Usul fi Sharh al-Maksul 1:138, 140 (Muhammad 'Abd al-Qadir 'Ata ed., Dar al-Kutub al-'Tlmiyya 2000).

26. Id. at $\mathrm{I}: 140$. 
the same way that a Mu'tazilite presumed these latter characteristics of God, he also knew that God seeks the preservation of the masalih (sing. maslaha) or general goods. By investigating general goods, the Mu'tazilites held that one can move from empirical investigations of benefits and harms to a determination of divine obligation. In other words, they united fact and value. They could do this because, by relying on a natural teleology, they invested creation with a divine purposefulness and hence a normative quality. Consequently, according to al-Qarafi, those who held that the Mu'tazilites believed reason alone obligates were incorrect in their understanding. ${ }^{27}$

The naturalist Mu'tazilites relied on a normative sense of nature, which is purposefilly created by God to satisfy human needs. Those needs are understood in terms of basic and general goods or masalih that God wants humans to achieve, and which are subject to rational analysis. From these goods, Basran Mu'tazilites were able to assert legal values and rules. Al-Qarafi illustrated this process by showing how the naturalists organized acts around the five categories of value, or the al-ahkam al-khamsa. These five categories are the basic divisions by which premodern Muslim jurists of all legal and theological affiliations determined the value of acts, whether as obligatory (wajib), recommended (mandub), permissible (mubah), reprehensible (makruh), or prohibited (haram/mahzur). ${ }^{28}$ Each value has a different consequence. For instance, an act that is obligatory (wajib) is an act for which one is rewarded by God for committing and punished by God for omitting. But an act that is merely recommended is an act for which one is divinely rewarded for committing, but for which no negative consequence arises if he omits the act. ${ }^{29}$

According to al-Qarafi, the Mu'tazilite naturalists held that where an act involves a purely or dominantly beneficial act (maslaha khalisa aw rajiha), one rationally knows that God wants humans to perform that act and obtain the benefit. If an act contains a purely or dominantly corrupt act (al-mafsada al-khalisa aw al-rajiha), God wants it to be omitted. If an act is free from both benefit and corruption, or if both balance each other out in a single act, then the act is deemed permissible $(m u b a h)$. But where an act poses a pure or dominant benefit, and the act involves a matter of a low level of significance (al-martaba al-daniyya), the act is merely recommended (nadb), whereby one receives a reward

27. Id.

28. Id. at $1: 138$.

29. Mohammad Hashim Kamali, Principles of Islamic Jurisprudence 413-431 ( $3^{\mathrm{d}}$ ed., Islamic Texts Socy. 2003). 
for committing it, but no consequences arise from omitting it. If the significance of the act is high (al-martaba al-ulya), the act is considered obligatory (wujub). On the other hand, if the act involves a pure or dominant harm, and the act poses a low level of significance, the act is reprehensible (karaha), where one is rewarded for omitting it, but no consequences follow if he commits it. If the significance is high, then the act is prohibited (tahrim) ${ }^{30}$ This description, albeit from an Ash'arite opponent, illustrates how Mu'tazilites could move from an empirical investigation into the circumstances and context of an act to a determination of divine obligation based on certain naturalistic presumptions. Inherent in the concept of maslaha or benefit is a sense of divine purposefulness that provides a normative quality to the underlying empirical observation. Consequently, Mu'tazilite naturalists like al-Jassas were able to move from an empirical observation of nature to a normative assessment of divine obligation without indulging any logical fallacy.

\section{Positivist Critique of Natural Law Teleologies}

The principal Positivist criticism against the naturalist position of the Mu'tazilites was that Mu'tazilites converted an empirical observation into a normative one. Or in other words, they tumed an "is" into an "ought", thus combining fact and value. This criticism suggests that one cannot move from an inquiry into empirical nature and assume that it necessarily implies or carries any normative value. Positivists denied that nature is either detenninative or normative. Nature, in other words, does not always pose masalih.

Often they would argue that human nature is such that one engages in things that scripture nonetheless prohibits. For instance, the Andalusian jurist Ibn Hazm (d. 456/1063) contended that God creates in

30. Al-Qarafi, supra n. 25, at 1:138-139. Al-Qarafi took pains to describe the Mu'tazilite naturalist view accurately and in fact castigated those who, in their opposition to the Mu' oversimplified or misrepresented Mu'tazilite theories. Id. at 1:140. He even argued that given the Mu'tazilite's premises, their naturalistic argurnents were in fact coherent. Consequently, al-Qarafi spent much of his analysis attacking the premises upon which the naturalists relied. So for instance, he said that the Mu'tazilites used the notion of maslaha to ground their obligations with both objectivity and nornativity. However they also relied on scripture as a basis for obligations. Al-Qarafi argued that it is possible that scripture may prohibit something that is rationally considered a maslaha, and as such the Mu'tazilite argument suffers from contradiction. Id. at 1:138-139. Furthermore, al-Qarafi contended that while the terms husn and qubh may anchor God's actions to a prevailing maslaha in theory, human ravional speculation cannot necessarily identify with determinacy what that maslaha is in any given case. Id at 1:148.149. Consequently, he later stated that husn and qubh do not capture the maslaha or mafsada of an act, but rather reflect God's determination of punishment and reward. Id. at 1:152. 
people desires that lead to misdeeds involving lewd behavior with beautifil women and handsome young men, the consumption of wine, abandoning the fight against unbelievers and sleeping during prayers. Yet God prohibits all of that for human beings via scripture. The point for Ibn Hazm was that one cannot make a teleological argument relying on natural creation, in this case human dispositions, to thereby render decisions on what is obligatory and what is prohibited. ${ }^{31}$ The Shafi'iteAsh'arite jurist Abu Hamid al-Ghazali (d. 505/1111) challenged those who argued that God's creation of foods with sumptuous flavors is evidence that He wants humans to benefit from His creation of such tastes. Al-Ghazali responded that both Positivist and naturalist jurists agreed that things like food have incidental qualities that inhere in them. But perhaps God creates savory flavor in food not so that one would benefit from enjoying it, but rather so that one could be rewarded for restraining his desirous self from eating it, just as one is rewarded for avoiding bad deeds that he otherwise desires to do. ${ }^{32}$

Abu Ishaq al-Shirazi (d. 476/1083), a well known Shafi'ite jurist, provided various reasons why the argument from a natural teleology does not work. He opposed the idea that nature was created to benefit mankind. This idea assumes that God acts only with a reason in mind, or with a rational purpose (mu'allila). Rather, al-Shirazi argued that God does as He wishes and rules as He desires (yaf'alu Allah ma yasha' wa yahkumu ma yuridu). ${ }^{33}$ Furthermore, he asked, if all of creation were for human benefit, how do the Mu'tazilites explain the scriptural prohibition on the consumption of wine and pork? Can one maintain that all of creation is for humanity's benefit, when in fact we find

31. Abu Muhammad 'Ali b. Hazm, al-Ihkam fi Usul al-Ahkam 2:54 (Dar al-Hadith 1984). Abu al-Ma'ali al-Juwayni, Ghiyath al-Umam fi Iltiyath al-Zulam 85 (Dar al-Kutub al-'Ilmiyya 1997). Al-Juwayni argued that the purpose of law and government is in fact to keep people's desires (hawa) restrained. Consequently, such desires, for al-Juwayni, cannot be the basis for nornative determinations of moral value.

32. Abu Hamid Muhammad b. Muhammad al-Ghazali, al-Mustasfa min 'Ilm al-Usul 1:154155 (lbrahim Muhammad Ramadan ed., Dar al-Arqam n.d.). See also Abu Bakr Ahmad b. 'Ali b. Thabit al-Khatib al-Baghdadi, Kitab al-Fagih wa al-Mulajaggih wa Usul al-Figh 193-194 (Zakaniya 'Ali Yusuf 1977); Abu Ishaq al-Shirazi, Sharh al-Lum'a 2:984 ('Abd al-Majid Turki ed., Dar al-Gharab al-Islami 1988). Al-Sam'ani (d. 489/1096) challenged those who argued for rational pennissibility and obligation on the grounds of a benefit found to reside in the act (manfa'a). He argued that the issue is not about whether there is benefit to an act, which thereby serves as the nonnative basis for the act's valuation. Rather what matters is whether there are indicators (imara) that the act contains some evil ( $q u b h$ ). In other words, one does not make affrnative rational presumprions of obligation. Rather one only negates obligation where there is an indication of evil. Mansur b. Muhammad b. 'Abd al-Jabbar al-Sam'ani, Qawati' al-Adilla fi alUsul 2:49-50 (Muharmmed Hasan Muhammad Hasan Isma'il al-Shafi'i ed., Dar al-Kutub al'Ilmiyya 1997).

33. Abu Ishaq al-Shirazi, supra n. 32, at 2:983-984. 
aspects of creation prohibited $?^{34}$ Perhaps, al-Shirazi suggested, such things were created for a people that will come later. If so, it is not appropriate to suggest that such things are presumptively permissible for us. Furthermore, he argued that the natural world may have been created in order to test humanity. Perhaps the test is that people are rewarded for avoiding certain things and restraining their desires. If these perspectives are all possible, then one can no longer proffer a naturalistic argument as the basis for divine obligation. ${ }^{35}$

This is not to suggest that positivist jurists did not consider the fact that as human beings, we make moral choices and determinations of the good (hasan) and the bad (qabih) all the time. Rather, they held that such detenninations do not and cannot have the force of a divine obligation. One may be able to assert notions of good or bad based on benefit and harm, but those notions do not have the stamp of the divine will. The Shafi'ite-Ash'arite jurist al-Juwayni (d. 478/1085), for instance, did not deny that one can rationally make determinations about avoiding danger (ijtinab al-mahalik) and initiating good (ibtidar almanafi'). To deny this, he said, would be "unreasonable" (khuruj 'an al-ma'qul). ${ }^{36}$ The capacity to make moral judgments is a natural endowment of human beings, or what al-Juwayni called the haqg aladamiyyin.

But making moral judgments is different from asking what is obligatory or prohibited in terms of God's determinations (hukm Allah). ${ }^{37}$ For al-Juwayni, God's detennination of an act's value is substantially different from a human determination on matters not addressed by God. The legal value of those acts addressed by God does not depend on a rational evaluation of harm or benefit. In other words, God does not legislate in the light of any rational calculus. Rather, relying on a divine command ethical model, al-Juwayni asserted that whether a determination by God is good or bad, and hence obligatory or prohibited, is dependent solely on whether God has provided punishment or reward for the relevant acts (wa ma kana kadhalik fa mudraku qubhihi wa husnihi min 'iqab Allah ta'ala iyana wa ihsanuhu ilayna 'ana af'alina). ${ }^{38}$ Such matters, according to al-Juwayni, are unknowable by humans (wa dhalika ghayb). ${ }^{39}$ Human beings cannot

34. Id.

35. Id. at 2:983-984.

36. Al-Juwayni, supra n. 4 , at 1:10.

37. Id.

38. Id.

39. Id. 
assess such divinely established matters by a rational analysis into harms and benefits since God is beyond such mundane affairs. This does not mean that humans cannot make determinations of good and bad. But they can only do so in those areas not already addressed by God. Furthennore, their determinations are not tantamount to God's will since God has not made a decision in these areas. Al-Juwayni stated:

it is not prohibited [for humans] to investigate these two characteristics [i.e., the good and the bad] where harm may arise or where benefit is possible, on condition that [the determination] not be attributed to God, or obligate God to punish or reward (lam yamtani' ijra' hadhayn al-wasfayn fina idha tanajjaza darrarun aw amkana naf'un bi shart an la yu'za ila Allah wa la yujibu 'alayhi an yu'aqibu aw yuthibu). ${ }^{40}$

By granting humans the ability to make moral determinations but not the ability to assert divine obligations, Positivists allowed for assessments of good (husn) and bad (qubh), but not obligation (taklif). Obligation could only exist by reference to scripture. Without scripture to rely upon, no one can assert a rule of divine obligation. Positivists would often hold that the ruling in such a case is in a state of suspension (tawaqquf). ${ }^{41}$ The rule may exist in the "mind" of God, but

40. Id.

41. Abu Baker Ahmad b. 'Ali al-Khatib al-Baghdadi, Kitab al-Fagih wa al-Murafagqih 192194 (n.p.: Matba'at al-Imtiyaz 1977); lbn Hazn, Ihkam fi Usul al-Ahkam 1:52; Abu al-Muzaffar Mansur b. Muhammad b. 'Abd al-Jabbar al-Sam'ani, supra n. 32, at 2:46-47, 52 (Muhammad Hasan Muhamad Hasan Isma'il al-Shafi'i ed., Dar al-Kutub al-'llmiyya 1997); Abu Ishaq alShirazi, supra n. 32, at 2:977; al-Qarafi, supra n. 25, at 1:173; al-Samarqandi, Mizan esl-Usul 1:314 (Lajnat lhya' al-Turath al-'Arabi wa al-Islami 1987). The Maliki al-Qassar wrote that some of his Maliki companions adopted this view, arguing that one needs proof (hujja) to establish something as either permissible or prohibited. Al-Qassar, al-Mugaddima fi Usul 153-155 (Muhammad b. al-Husayn al-Sulaymani ed., Dar al-Gharb al-Islami 1996). In other words, one cannot rely on reason to create obligations where there is no scripture. But for al-Qassar, there is no situation that is without a scriptural basis. The prophets after Adam have decided all matters of obligation, and as such there is nothing that has not been addressed. Muhammad Fayd al-Hasan al-Kankuhi said that where what is at stake is the question of reward and punishment, the Ash'arites argued that such detenninavions can only come from scripture. Muhammad Fayd alHasan al-Kankuhi, 'Umdat al-Hawashi, in Abu 'Ali al-Shashi, Usul al-Shashi 143 (Dar al-Kitab al-'Arabi 1982). 'Al Lamishi wrote that this position was held by the Maturidites, the positivists (ashab al-hadith), and some Mu'tazilites. Al Lamishi, Kitab fi Usul al-Fiqh 105 ('Abd al-Majid Turki ed., Dar al-Gharb al-Islami 1995). For him, there is no room for reason to establish obligations (la hazz li ['agl] fi ma'rifa al-ahkam al-shar'iyya). In matters not addressed by scripture, there is no rule of law. Al-Farikan wrote that this is the position adopted by the majority of Ash'arites. Taj al-Din 'Abd al-Rahman b. Ibrahim Ibn al-Farikan, Sharh al-Waragat 347-350 (Sarah Shafi al-Hajiri ed, Dar al-Basha'ir al-Islamiyya 2001). Interestingly, Abu Hamid alGhazali said that a group of Mu'tazilites adopted this view as well. Although their position of waqf was one that held that wbile there is no obligation without scripture, acts still have essential characteristics that reason can investigate. Abu Hamid al-Ghazali, supra n. 32, at 1:151, 153. See also al-Samarqandi, Mizan al-Usul 1:314, who listed Mu'tazilites who adopted the position of 
epistemically, humans cannot know what the rule is.

But even if the rule is suspended, that does not change the fact that a person needs to know how to act in a given situation. Simply saying that humans can make moral decisions without the imprint of divine obligation arguably will not satisfy the laity, who are interested in acting in a way that avoids divine reprimand. Positivist jurists often relied on a theoretical back door that allowed them to get around this problem, namely the interpretive instrument of istishab al-hal or the presumption of continuity. Under this rational presumption, where no scripture asserts a specific obligation, one is presumptively free from any liability for what he chooses to do (al-asl bara'at al-dhimma). ${ }^{42}$ For instance, Abu Walid al-Baji (d. 474/1081) offered the question of whether the witr prayer is obligatory or not. Witr is a sixth prayer performed after the required fifth late evening prayer of the day. Jurists debated whether this sixth prayer is obligatory or not. According to al-Baji, a Hanafite jurist may ask a Malikite jurist about whether this prayer is obligatory. The Malikite will say it is not obligatory. ${ }^{43}$ When the Hanafite inquires about the Malikite's basis for his determination, the Malikite responds:

The presumption is freedom from liability (bara'at al-dhimma) and the path to obligation is through scripture (shar). I have searched the scripture and did not find anything obligating [witr prayer]. If it were there, I would have found it with extensive research and investigation (kathra al-bahth wa al-nazar). So [the matter is decided] pursuant to the rule of the presumption of freedom from liability. ${ }^{44}$

According to al-Baji, the path to obligation is through scripture, and because of that he knew that Muslims are not obligated to pray a sixth prayer, pay an additional alms tax (zakat) or fast in a month outside of Ramadan. ${ }^{45}$

For Abu Hamid al-Ghazali, although the rules of scripture cannot be known independently by reason, one can rationally determine that one is otherwise free from divine reprimand where there is no scripture. The absence of rules can be rationally known epistemically, and

tawagquf. He also mentioned that the Positivists (ashab al-hadith) adopted this position as well.

42. Abu Walid al-Baji, Ihkam al-Fusul fi Ahkam al-U'sul 2:700 (2 ed., 'Abd al-Ma jid Turki ed., Dar al-Gharb al-Islarni 1995).

43. Notably, the Hanafites argued that witr prayer is obligatory and based their ruling on traditions of the Prophet. But the Hanafites did not consider those who reject this obligation to be heretics. Abu al-Hasan 'Ali b. Abi Baler al-Farghani al-Marghinani, al-Hidaya: Sharh Bidayat alMubtadi' 1:80 (Muhammad Darwish ed., Dar al-Arqam n.d.).

44. A bu Walid al-Baji, supra n. 42, at 2:700.

45. Id. 
consequently that state of absence continues unless proven otherwise by express scriptural legislation. ${ }^{46}$ Therefore, while the presumption of continuity is a rational presumption, it is not tantamount to the Basran Mu'tazilites' presumption of permissibility. The presumption of permissibility is a positive rational assertion about the value of an act based on the underlying ontological authority of reason to bring obligations into being. The presumption of continuity, on the other hand, is an epistemological rational proof based on the absence of scripture. The absence can be known epistemically by reason, and consequently where there is no scripture, there is no threat of blame or punishment. Under both approaches, the actor is free from any blame or reward. But while the outcome of the presumption of continuity may be the same as the principle of pernissibility, the role of reason in each presumption is different. ${ }^{47}$ Fundamentally, the presumption of continuity does not enable or empower reason to assert a divine obligation. Divine obligation remains tied to scriptural text.

\section{Positivist SOFT NATURALISM}

Despite the fact that Positivist jurists like those noted above denied a role for reason in establishing obligations, some nonetheless recognized that one would have to rely on juristic discretion to determine rules of Shari'a. The presumption of continuity was simply a rule of non-liability; but it was not a tool for asserting positive obligations in situations where scripture was silent. The fundamental challenge Positivists jurists faced when addressing the use of juristic discretion to detennine new rules of Shari'a concemed how to justify the resort to such discretion. Ultimately jurists such as the Ash'ariteShafi' ite al-Ghazali, for example, adopted a softer naturalism than al-

46. Abu Hamid al-Ghazali, supra n. 32, at 1:585.

47. On the role of istishab al-hal for those who adopted the tawagquf position of suspension. see al-Qassar, supra n. 41, at 157; al-Khatib al-Baghdadi, supra n. 41, at 191-192; Abu Ishaq alShirazi, supra n. 32, at 2:986; al-Lamishi, Kitab fi Usul al-Figh 188 ('Abd al-Majid Turki ed., Dar al-Gharb al-Islami 1995). The Andalusian Zahiri jurist Ibn Hazm presented a different way to deal with this situation. He questioned those who argued that in cases where there is no scripture, one must avoid such matters out of precaution (ihtiyat). But Ibn Hazm argued that this approach cannot be used as a basis for prohibition since it does not produce certain knowledge, but rather only probable knowledge (zann). Ruling by ihtiyat is to tule by zann, and ruling by zann is to rule by deceit (kadhb). For Ibn Hazm, the rule pursuant to ihtiyat seems to be based on a notion of piety rather than legality. Rather, since God has specifically stated that all of creation is for human benefit, the presumption of ihtiyat counters the very terms of scripture. Rather for Ibn Hazm, the existence of things in the world, coupled with God's permissive attitude toward utilizing them, constitutes the basis for what is effectively a freedom from liability for partaking in such matters. Ion Hazn, supra n. 41, at 2:180-189. 
Jassas' Mu'tazilite variety. Mu'tazilite naturalism recognized the normativity of nature in a way that implied not only that God would act with a purpose, but that He only does the good. ${ }^{48}$ Positivists found this implication to be an infiingement on God's omnipotence. Consequently, although they relied on a naturalist thesis to justify juristic discretion, Positivists designed their naturalism in a way that preserved God's omnipotence. To illustrate this soft naturalism, I will focus on the work of al-Ghazali.

Al-Ghazali's soft naturalism relied on both divine grace ( $\mathrm{fadl}$ ) and accepted authorities (scriptural and consensual) as a justificatory foundation for any incorporation of nature as a basis for extending and creating law. He erected a model of discretion that relied on intuition, a theology of God's grace, and inductive reasoning from scripture, by which he crafted basic aims and goals of the legal system. He argued that these aims of the legal system or the magasid were those that any legal system or community would uphold; and he illustrated the existence of those aims in Shari'a by reference to various scriptural rules in the law. These basic aims provided the telos of the law-a telos based on an intuitive sense of the good. This soft naturalism is still a form of naturalism because al-Ghazali would determine whether a particular good (maslaha) satisfied one of the basic aims of the legal system and could be a normative basis for generating a rule of law.

This resort to maslaha is tantamount, I argue, to incorporating a naturalistic account into the legal interpretive process. Maslaha is defined as the salah or something that poses a good. ${ }^{49}$ Through adopting the maslaha as a basis for legislation, al-Ghazali fused the empiricism of nature and the good with a scripturally justified normativity that could serve as the foundation for discretion-based obligation. He based the normative value of masalih (sing. maslaha) on the foundation of scripture and demanded a rational nexus between the maslaha and the basic aims of the law. But once maslaha was detennined to be a foundation for generating law, the maslaha became the focal point for al-Ghazali's soft naturalism. By fusing fact and value by reference to both nature and scripture, al-Ghazali avoided the hard naturalist models adopted by Mu'tazilites such as al-Jassas that fused fact and value in a way that some argued required God to act purposefully for the good,

48. For a discussion of the early Mu'tazilite debates on of God's justice and His persistence in doing the good, see W. Montgomery Watt, The Formative Period of Islamic Thought 238-242 (1973; repr. Oneworld Publications 1998).

49. Ibn Manzur, Lisan al-'Arab 2:517 (3d ed., Dar Sadir 1994); al-Zabidi, Taj al-'Arus 4:125126 ('Ali Shiri ed., Dar al-Fikr 1994). 
thereby undermining God's omnipotence. Rather, for the soft naturalists, the good or maslaha in nature was a product of divine grace. We can take it into account because of scriptural indicators that render it a normative source for inquiry. But because its goodness is the product of divine grace, God can change His mind and alter nature in a way that does not provide the good in any dependable fashion. Consequently, by combining intuition, scriptural foundations, and a theory of divine grace, al-Ghazali crafted a model of soft naturalism that relied on nature as a justificatory foundation for discretion, but preserved God's omnipotence and voluntarism by building his soft naturalism on the pillars of scripture and divine grace.

This essay will focus on two of al-Ghazali's works on the topic of maslaha, namcly Shifa' al-Ghalil and his monumental study on usul alfigh called al-Mustasfa min 'Ilm al-Usul. Shifa' al-Ghalil seems to have preceded al-Mustasfa, and al-Mustasfa represents al-Ghazali's matured ideas on the topic of legal theory. ${ }^{50}$ In the discussion on maslaha and its related technical terms, the discussions in both works parallel each other, with some differences. This study will focus primarily on al-Mustasfa, while indicating where al-Ghazali modified his earlier views by reference to relevant passages from Shifa ' al-Ghalil.

For al-Ghazali, to discuss any procedure for generating rules by reference to benefits or maslaha, one must first know what a maslaha is. Generally, the term maslaha can refer to anything that allows one to obtain a benefit (jalb manf $a^{\prime} a$ ) or to repel a harm (daf' madarra). ${ }^{51}$ But al-Ghazali's use of the term had a more technical meaning than this general linguistic understanding. Certainly, the aim of all creatures (magasid al-khalq) is to obtain benefit and repel harm. This, however, does not mean that maslaha has this meaning for the purposes of a legal methodology. As a legal term of art, maslaha refers to any interest that upholds and preserves the purposes articulated within the divine law $(\mathrm{al}$ muhafiza ala maqsud al-shar'). ${ }^{52}$ These purposes or basic aims of the law consist of five values, namely the preservation of religion (din), life (nafs), reason ( $a q l)$, lineage (nasl), and property (mal). "Whatever involves the preservation of these five fundamental values is a maslaha, and whatever neglects these fundamental values is corrupt, and so

50. Abu Ishaq b. Ibrahim b. Musa b. Muhammad al-Shatibi, al-I'tisam 2:608 (Salim b. 'Id alHalali ed., Dar Ibn 'Affan 1997).

51. Al-Ghazali, supra n. 32, at 1:636. Ibn Manzur, Lisan al-'Arab 2:517, defined the term as the good or salah. For the same definition, see al-Zabidi, supra n. 49, at 4:125-126.

52. Al-Ghazali, supra n. 32, at 1:636. 
repelling it is a maslaha."

Al-Ghazali illustrated these five purposes of the law by referring to various scriptural examples. For instance, punishing a heretic who spreads his heresy upholds and protects the value of religion. ${ }^{54}$ The value of life is upheld by the punishment of execution for murder or retribution for a physical injury (i.e., gisas). ${ }^{55}$ The punishment for consuming alcohol upholds the virtue of having a sound mind, ${ }^{56}$ while the punishments for fornication and adultery protect the integrity of family and lineage. ${ }^{57}$ And finally, the punishments for theft and usurpation maintain the basic aim of upholding property interests. ${ }^{58}$

Importantly, the foundation for these values is a type of inductively based intuition. Certainly scriptural rules and provisions uphold these values. But for al-Ghazali, these values are the kinds of values that any society or legal tradition would uphold if it values the preservation and flourishing of society. He stated:

It is impossible that any society (milla min al-milal) or any legal system (shari'a min al-shara' $i$ '), which aims to benefit creation (islah al-khalq) would not include prohibitions against neglect of and restraint from these five values. ${ }^{59}$

According to al-Ghazali, it was not surprising that no legal system differed over certain prohibitions, such as the prohibition of disbelief (kufr), murder ( $q a t l)$, fornication and adultery (zina), theft (sariqa), and consuming intoxicating substances (sharb al-muskir). ${ }^{60}$ Any maslaha at issue must in some way appeal to these basic five values. In other words, the maslaha must pose a nexus to the basic values before it can be utilized as a ground or foundation for a legal rule.

But not every maslaha that poses a nexus to the basic purposes is a valid basis for a rule of law. Al-Ghazali judged the masalih (sing. maslaha) by reference to different relationships that they have to both the basic aims above and to the body of scripture inductively analyzed. Concerning the relationship of the maslaha to scripture, al-Ghazali divided the masalih into three categories. For instance, some masalih are positively affirmed by scripture. These affirmed masalih are what al-Ghazali called mu'tabar. An example of this kind of maslaha would

53. Id.

54. Id. at 1:637.

55. Id.

56. $I d$.

57. Id.

58. Id.

59. Id.

60. Id. 
be the prohibition of any intoxicant. Certainly there is Qur'anic scripture that condemns the consumption of wine. One can use this textual reference to wine as a basis for creating a more general prohibition against all intoxicating substances on the ground that prohibiting intoxicants upholds and protects the integrity of the mind. Although scripture is not express on intoxicants generally, nonetheless a rule by precedent (qiyas) can extend the ban on wine to include a ban on all intoxicants. ${ }^{61}$ Importantly, though, this is not technically a rule based on maslaha. Rather this is a rule by precedent (qiyas), according to alGhazali, and consequently is not central to an inquiry into al-Ghazali's soft naturalism.

On the other hand, a maslaha might be expressly rejected in the scripture. Al-Ghazali mentioned as an example the case of a king who has sex during the day in the month of Ramadan. Jurists debated how he should expiate the sin of breaking his fast deliberately in this fashion. The Qur'an stipulates as expiation that one should free a slave. But if one cannot do so, then he should fast for two consecutive months. And if that is not possible, he should feed sixty indigent people. ${ }^{62}$ Some jurists argued that a king should fast two consecutive months and not free a slave, though the latter expiation is mentioned first in the Qur'anic verse, and takes priority over the other forms of expiation. Such jurists held that since the king has such great wealth, freeing a slave does not pose a significant deterrent to him. Consequently, in order to deter him from breaking his fast, he should be required to fast two consecutive months instead. However, for al-Ghazali, this view was invalid despite the fact that it was based on a reasonable maslaha. This rationale contradicts the text of the Qur'an, which provides for al-Ghazali a clear statement of the priority in which the expiations should be applied to the wrongdoer. To open the door to this kind of maslaha, argued alGhazali, would lead to a change in all the limits of the law (hudud alshara ${ }^{\prime}{ }^{\prime}$ ) because of changes in circumstance or context. ${ }^{63}$ Such interpretations would undennine determinacy in the law, and would reduce the integrity of jurists among the people. ${ }^{64}$ Again, however, this particular type of maslaha is not central to an inquiry into al-Ghazali's soft naturalism. This type of maslaha illustrates the ongoing importance

61. Al-Ghazali, supra n. 32, at 1:634-635.

62. Qur'an 58:3-4. This verse actually addresses the expiation for illegitimately rejecting one's wife and marital union through the mechanisms of zihar. However as jurists such as alMarghinani suggested, the expiation for violating the fast was the same as for engaging in zihar. Al-Marghinani, supran. 43, at 1-2:150.

63. Al-Ghazali, supra n. 32, at 1:635.

64. Id. 
and centrality of scripture in al-Ghazali's legal methodology, and is arguably offered to circumscribe the extent to which maslaha values are incotporated into the law.

The last category of maslaha to be considered in the light of its nexus to scripture is the one on which scripture is completely silent. There is no express adoption or rejection of this maslaha by any specific textual indicator (nass mu'ayyan). ${ }^{65}$ This type of maslaha is the one that can be the basis for generating de novo rules of law. This third and final maslaha is central to al-Ghazali's soft naturalism. It represents the area where a jurist utilizes greatest discretion, since the other masalih are either accepted or rejected by scripture. And it is in justifying the discretion used to deal with silent masalih that we find al-Ghazali developing his natural law theory.

To further ensure that a silent maslaha can be a proper basis for discretionary legal interpretation, al-Ghazali required a second nexus between a silent maslaha and the five goals or aims of the legal system. A silent maslaha can pose a nexus to the basic aims of the Shari'a in three different ways. It can present a necessary interest (darurat) for fulfilling the basic aims of the legal system, in which case such a maslaha is of the highest order. Alternatively, it can pose only a basic need (hajat), where the maslaha is deemed important, but does not rise to the highest level of social interest. And lastly, a silent maslaha can present an edificatory interest that speaks to underlying cultural norms (tazyinat, tahsinat) ${ }^{66}$ The silent maslaha is divided into these three subcategories that represent its significance ( $q u w w a$ ) or degree of nexus to the five basic values. ${ }^{67}$ Underlying each of these categories of interests are subsidiary interests that supplement or perfect the primary rules of these categories (takonila, tatimma). ${ }^{68}$

Examples of necessary interests might be those that uphold the five basic values, such as punishments for consumption of alcohol, murder, and adultery. Of course, those are punishments based on scriptural texts and not silent masalih; however, they illustrate the kind of nexus alGhazali had in mind when addressing the silent masalih that posed necessary interests. An example of a maslaha that poses only a need might be the rule empowering a guardian (taslit al-wali) over a minor in matters of marriage. This is not a necessary interest given that the marriage of minors is not significant for preserving society. It is a rule

65. Id. ai 1:635-636.

66. Id. at 1:636.

67. Id.

68. Id. at 1:635-636. 
that ensures that the minor marries someone who is suitable. "But this is not like empowering the wali over upbringing (tarbiyatihi), nursing (irda'ihi), and buying clothing and food." 69 These latter responsibilities pose necessary interests with a tight nexus to the basic aims of the law. In fact, they are so central to society that no disagreement in the law on such issues can be imagined, according to al-Ghazali. ${ }^{70}$ Marriage of a minor does not pose such a necessity. According to al-Ghazali, the longings of desire do not arise in children (fa la yarhaqu ilayhi tawaqan shahwa), nor the need to procreate. Rather, such marriages are intended to improve one's situation by linking clans (ishtibak al-'asha'ir). ${ }^{71}$ Such matters do not pose a necessary link to the five basic values. The rational nexus between the maslaha and basic values is thereby too weak to rise to the level of a necessity.

The weakest nexus that a silent maslaha can pose to the basic values is one that is neither necessary nor needed, but rather raises a society's level of excellence (mazaya) and perfection by upholding the best course of conduct in the light of customary practice and interpersonal dealings (ri'ayat ahsan al-manahij fi al-'adat wa almu'amalat). ${ }^{72}$ In other words, this sort of silent maslaha is one that respects certain cultural norms of what it means to have a fulfilled life and a well-developed society. One example al-Ghazali provided to illustrate this kind of interest is the rule denying the slave any capacity to give testimony in court (salb al-'abd ahliyya al-shahada). ${ }^{73}$ The reason al-Ghazali gave was that slaves are of a lower social rank due to their subordinated status below their master. "It is not appropriate to [the slave's] station that he issue testimony." "Wh "Whe issuing testimony in court held a certain social meaning concerning social status, slaves were denied any participation in this activity. However, the rule denying them this capacity posed the lowest level of a rational nexus to the basic values. In contrast to this, the rule denying slaves the capacity to be a guardian over a minor appeals to a general need (haja). In other words, denying a slave the capacity to be a guardian over children involves a public interest of greater importance than denying the slave the capacity to testify in court. Where guardianship over a minor in general posed a darura interest, denying the slave this capacity was only

\footnotetext{
69. Id. at $1: 638$.

70. Id.

71. Id

72. Id. at $1: 639$.

73. Id.

74. Id.
} 
a haja. The slave was denied this capacity because, according to alGhazali, guardianship over a minor requires significant time and commitment; but the slave is already burdened with service to his master. Consequently, "delegating the matters of children to him would cause an injury to the children." 75

Al-Ghazali addressed the silent maslaha in this fashion to make a significant and central point in his soft naturalism. Namely, he stated that silent masalih that only pose a need (haja) or vindicate an edificatory interest (tahsin/tazyin) cannot be the basis for creating new rules of law where there is no supporting evidence from a recognized source of law (shahadat asl). ${ }^{76}$ In other words, the two lowest categories which pose the weakest nexus to the basic values of the legal system cannot provide a basis for any rule of law by themselves. Rather, only the category posing the strongest nexus to basic values, namely the darurat, can be the basis for juristic interpretation and legal analysis. As al-Ghazali stated, "it is not farfetched that the interpretation of a jurist would lead to such a [darura-based] rule although no specific source of law exists as evidence for it," ( $\mathrm{fa}$ la bu'd fi an yu'di ilayhi ijtihad mujtahid wa an lam yash-had lahu asl mu'ayyan). ${ }^{77}$

To illustrate how his notion of necessary silent masalih can provide a basis for generating rules of conduct, al-Ghazali presented a series of examples. Through the use of these hypotheticals, al-Ghazali further limited the scope to which masalih can be used in legal analysis. In particular, his examples illustrate that before any maslaha can constitute a basis for a rule of conduct, it must satisfy three conditions. The first condition was noted above, namely that the maslaha must pose a necessary interest (darura) that presents a tight nexus to the goals of society and the legal system. ${ }^{78}$ Darura interests are those that seek to effectuate the most compelling issues in society in the light of the five values noted above. The second condition is that there must be a certainty (qat'iyya) that the interest at stake in a given situation can be satisfied by the proposed course of conduct. ${ }^{79}$ But what al-Ghazali

75. Id.

76. Id. at $1: 640$.

77. Id. at 1:640-641. Notably, in his earlier work, Shifo 'al-Ghalil, al-Ghazali stated that one could rely on both the haja and the darura for independent analysis, as long as they inductively pose a nexus to the body of Shari'a (kana mula'iman li tasarrufat al-shar'). However, the third weakest category could not be used for such analysis. Abu Hamid Muhammad b. Muhammad b. Muhammad al-Ghazali, Shifa' al-Ghalil fi Bayan al-Shabh wa al-Mukhil wa Masalik al-Ta'lil 208-209 (Muhanmad al-Kubaysi ed., Ra'asa Diwan al-Awqaf 1971).

78. Id. at 1:640-641.

79. Id. at I:642. 
meant by certainty will be addressed below. And last the interest served must be for the benefit and perfection of society at large and not for a defined group of people or special interest group. Al-Ghazali used the term kulliyya to capture this final condition of scope. ${ }^{80}$ Consequently, while al-Ghazali seems to have adopted a type of soft naturalism premised on intuitive basic goods and maslaha as foundations for juristic discretion, he made considerable effort to limit the scope and extent to which this sort of naturalistic discretion was utilized in the law.

An example of where al-Ghazali derived rules in the light of these three conditions involves a hypothetical where unbelievers waging war against a Muslim army utilize innocent Muslims as human shields to protect their front line. Al-Ghazali asked whether in this situation, the Muslim army can fire upon the unbelievers knowing that in doing so, the Muslim army will kill the Muslims used as shields. The answer to this question involved a context sensitive inquiry into the nature of the interest involved. He wrote:

If we refrain from [the unbelievers] they will charge into us and conquer the land of Islam and kill the rest of the Muslims. But if we strike at the shield, we shall kill a Muslim who is innocent and who has committed no infraction. There is no knowledge of this in the law. If we refrain, the unbelievers will take power over all the Muslims and will kill them, and then will kill the prisoners [used as a shield]. So it is possible that one could say: "This prisoner will be killed in any case." Protecting all the Muslims poses a tighter nexus (agrab) to the aim of the law because we know with certainty (gat) that the aim of the law is to reduce killing, just as it aims to terminate killing entirely where possible. If we arc not ablc to terminate [killing] we can reduce it. This involves a resort to a maslaha whose nature as a goal of the law is known by necessity ( $b i$ darura), not by one piece of evidence or a specific scriptural source, but by evidence beyond estimation ( $b i$ adilla kharija 'an al-hasr).

If instead the enemy was fortified in a castle and still used Muslims as human shields, the analysis would change according to al-Ghazali. In this case, the Muslims cannot be certain that they can conquer the enemy in the castle, given its fortifications. Furthermore, conquering the castle does not pose a necessary interest as the non-Muslims penned up inside do not pose a risk to Muslim lands. ${ }^{82}$

80. Id.

81. Id. at $\mathrm{I}: 641-642$.

82. Id. at $1: 642$. 
This is not to suggest that al-Ghazali relied on a stark utilitarian calculus conceming the good of the many. His approach to maslaha is not about maximizing the good while a minority bears the burden of the expense. Rather, his approach seems to involve a conception of the good that speak to the aims of society and its attainment of the telos of its own perfection. For instance, al-Ghazali posed a second example about a boat that is sinking. Suppose the passengers come to the conclusion that if they throw one person over board, chosen by lottery, the boat will not sink and the rest of the passengers can be saved. They may be certain about this fact, and certainly it poses a necessity in the light of preserving life. But for al-Ghazali, the condition of scope is missing. The interest served is not kulli because those affected by the sinking boat are limited in number. The injury the passengers would suffer is not tantamount to the massive destruction that could be imposed on Muslim society at large if the enemy were to make advances in battle and conquer Muslim land. ${ }^{83}$ The scope of interest is not the same in the two hypotheticals noted above. The condition that a maslaha pose a universal value for all of society suggests that what is at stake is more than just a utilitarian principle of maximizing happiness. Rather, what seems to be at play is a preconception of what benefits society at large and will contribute to its advancement and perfection. The law is not intended to be a tool for specific groups. It embodies an aim and goal for society at large.

Another example Al-Ghazali used involves beating someone suspected of having stolen property. Certainly to beat him and obtain a confession poses a positive public interest. Al-Ghazali even noted that Malik b. Anas allowed this practice ${ }^{84}$ However al-Ghazali rejected its use. He admitted that torture serves the interests of achieving resolution of criminal activity. But it conflicts with another public interest demanding protection for the alleged thief.

Perhaps [the alleged thief] is innocent of the infraction. Omitting physical injury on a guilty person is less important (ahwan) than hitting the innocent. In hitting is an open door to deterring theft, but in hitting is an opening to punishing the innocent. ${ }^{85}$

Certainly torture can present some benefit to law enforcement officials as they seek to apprehend criminals. But it conflicts with a competing maslaha that has greater weight. The greater weight of the defendant's

83. Id.

84. Id. at $1: 643$.

85. Id. at $1: 642-643$. 
rights is represented by al-Ghazali's use of the term ahwan, which is an evaluative term about the relative weight of the two maslaha interests involved here. How he strikes this balance is left unexplained. Perhaps like his basic goods, he relies on intuition.

Suppose someone causes corruption in the land to achieve social discord (fitna). Is it lawfill to kill this person? Certainly there is a public interest in doing so. But does it rise to the level of a maslaha on which we can base legal conduct? Al-Ghazali answered that the resolution to this question depends on the circumstances. If the individual has not engaged in any criminal activity requiring his execution, the authorities should imprison him only. Life imprisonment (takhlid al-habs 'alayhi) is sufficient to meet the evil that this person wreaks on society. ${ }^{86}$ There is no need to kill him, according to alGhazali, who said that "this maslaha is not darura."87

In other words, al-Ghazali balanced the need to protect human life and limit govemment uses of violence with the need to ensure public order by using his maslaha schematic to analyze the necessary rule of law that can govern this situation in a way that poses the best and most suitable nexus to the overall goals of the legal system. But suppose that this agitator lives in an era of extreme social discord and the existing government may be toppled any day, and cannot guarantee that it can keep the agitator imprisoned for life. And further suppose that imprisoning the agitator for life will only increase his anger and hatred. In this case, is it permissible to kill the agitator? For al-Ghazali, these circumstances raise important questions, but at the same time are purely speculative. There is no way to deternine what will happen in advance, and one cannot thereby operate on what is tantamount to mere conjecture and speculation (hukm bi al-wahm) ${ }^{88}$

This last hypothetical takes al-Ghazali back to his first hypothetical concerning the enemy who uses Muslims as human shields. Suppose the Muslim anny is not certain that the non-Muslims will exterminate Islam from the land if the shields are left intact, but only knows that this is likely to happen (bi ghalabat al-zann) ${ }^{89}$ Is this sufficient for allowing the Muslim army to fire on the Muslim shields? For al-Ghazali, firing on the human shields is permitted if one can reach certainty that it is necessary, or if not absolute certainty, then at least a degree of likelihood

86. Id. at $1: 644$.

87. Id. at $1: 643-644$.

88. Id. at 1:644.

89. Id. 
that approximates certainty (al-qat' aw zann qarib min al-qat'). ${ }^{90}$ But even then, this type of near certainty can only be relied upon in those circumstances where the interest is of such universal scope and grave significance (sara kulliyjan wa 'azuma al-khatar fihi) that people consider the matter very important. ${ }^{91}$ In other words, between certainty and mere speculation is a middle ground where something less than certainty may suffice to support a rule of conduct in a case where no specific scriptural precedent exists but which poses a gravely significant matter that has society-wide ramifications.

Of course, this hypothetical runs into one major scriptural conflict, namely those verses of the Qur'an that prohibit killing a believer intentionally or killing one without a right against him. ${ }^{92}$ Is it possible to justify killing Muslim human shields on the basis of a maslaha where that maslaha seems to contradict scriptural prohibitions quite starkly? AI-Ghazali was keen to suggest that he is not advocating a type of utilitarian inquiry into what benefits the many over the few. This, he suggested, was evident in his hypothetical about the sinking boat. Rather, he argued that in this case one must first investigate the totality of the law. "We know that the law prefers the universal scope (al-kulli), over the particular or narrow scope ( $a l$-juz ' $i)$., ${ }^{93}$ Protecting the people of Islamic lands from their enemies is "more important for the aims of the law (ahamm fi maqsud al-shar') than protecting the life of a single Muslim." 94 And importantly, for al-Ghazali's intuitively based soft naturalism, this knowledge of the law's purpose is so certain and clear that it does not need any specific scriptural evidence to say so. Specifically he stated that this purpose's "certainty is not in need of any evidence" (wa al-maqtu' bihi la yahtaju ila shahadat asl). ${ }^{95}$

While al-Ghazali utilized other examples to illustrate his point about the use of maslaha, the above examples show how he created a system of interpretation that relied on the empiricism of reality to enshrine normative values and rules of conduct. His resort to intuition about the basic goods of society provided him with universal values that served as the telos of his interpretive system. The masalih that he identified posed public policy questions that addressed no specific party in interest, but rather focused on society as a whole and its pursuit of

90. Id. at 1:644-645.

91. Id.

92. See Qur'an 4:92-93, 5:32, 17:33.

93. Al-Ghazali, supra n. 32, at 1:647.

94. Id.

95. Id. 
perfection both at the individual and communal level.

Notably, al-Ghazali emphasized that the maslaha analysis was not a purely rational inquiry into the law. Rather he suggested that it was fundamentally based on scripture. He said that maslaha is not a fifth source of law, alongside the Qur'an, Sunna of the Prophet, consensus (ijma') or rule by precedent (qiyas). ${ }^{96}$ Rather legislating by resort to maslaha involves upholding the purposes of the law as articulated in the Qur'an, Sunna and ijma' in some fashion (hafz maqasid al-shar'). ${ }^{97}$ Whether one looks to the totality of these sources (tasarrufat al-shar') to inductively justify a maslaha or to corroborate basic values and goods, a maslaha analysis implicitly relies on these sources and consequently cannot be an independent source of law. ${ }^{98}$

This is not to say that ruling by maslaha is tantamount to rule by precedent or giyas. Rather, qiyas relies on a specific indicator (asl mu'ayyan). Ruling by maslaha is intended to fulfill and satisfy a basic aim of the law that is known not by a single piece of evidence but by an inestimable amount of evidence from the Qur'an, Sunna, the context of situations, and various separate indices (bi adilla kathira la hasr laha min al-kitab wa al-sunna wa gara'in al-ahwal wa tafariq al-imarat). ${ }^{99}$ Consequently, the basic purposes of the law are not solely captured by some inductive analysis of scriptural text. Rather, the full totality of circumstances, both textual and contextual, plays into the determination of the basic goods of society and the law. These goods are known intuitively, and as such, a maslaha that poses the necessary nexus to those goods can be the basis for a rule of law.

Important to this discussion is how al-Ghazali justified his resort to maslaha while distinguishing it from Mu'tazilite naturalism. Mu'tazilites like al-Jassas argued on the grounds of a rationally based natural teleology that they could fuse fact and value, thereby rendering nature normative by default. It was as if they could say that God is bound to uphold the good and the beneficial by the very essence of nature. Al-Ghazali was keen to distinguish his resort to naturalism from the harder naturalism of the Mu'tazilites. Consequently, we find alGhazali stating in no uncertain terms that his resort to maslaha as a basis for rules of law is not to be understood as an adoption of the Mu'tazilite argument that God is obligated to do the good. But this does not mean that he refused to fuse fact and value. Rather the issue is how he fused

96. Id. at $1: 652$.

97. Id.

98. Id. at 1:652-653.

99. Id at 1:652-654 
them. He fused fact and value in the light of both a jurisprudence that is premised on the basic aims of the law that he considers intuitively known, and a divine voluntarism that preserves God's omnipotence while normativizing the facts of nature. For instance when writing about the darurat maslaha values, he said that they are the goal of the divine legislator (maqsud al-shari') and constitute necessities for creation (darurat al-khalq). Importantly, he stated:

Reason indicates them and decides upon them whether or not there is law (lau la wurud al-shara' $i$ '). [They] are those for which no law can be without according to those who speak of the good and the bad as rational matters (tahsin al-'aql wa taqbihihi). We say: It is for God most high to do as He wishes with his servants; it is not obligatory on Him to uphold the good (ri'ayat al-salah). [But] we do not deny the power of rational capacities to indicate the beneficial and the corrupt (al-masalih wa al-mafasid), and their ability to wam against hann and to desire obtaining bounties and fillfillment. Nor do we deny that the prophets, on them be peace, were sent for the benefit of creation in matters of this world and religion (li masalih al-khalq $f i$ al-din wa al-dunya) as a mercy and grace from God on creation (rahma, fadl), and not lbecause of] an imposition or obligation on Him. God most high said: "We did not send you except as a mercy for the world," and so on from verses that illustrate as much. Indeed we have explained [ourselves] to this extent in order that we not be associated with the beliefs of the Mu'tazila (i'tiqad al-i'tizal). ${ }^{100}$

Al-Ghazali argued that one can rationally investigate the empirical good and bad. But the normativity of that assessment is based on a theory of divine creation that preserves God's omnipotence. The fact that al-Ghazali can fuse fact and value in his use of maslaha is based solely, according to him, on the fact that God out of His grace and mercy provides benefit to human beings through His act of creation. The normativity of nature is established in the light of a voluntarism that maintains the willfulness of God, denies any obligations on God, yet upholds a teleology linked to a normative nature whose normativity is the product of a willful divine grace. Maslaha thereby fuses both the empiricism of nature and normative value without indulging in a natural teleology that has the theological implications of imposing on God obligations to do the good. Under al-Ghazali's version of nature, God is not bound to do the good. But He does so out of His choice and will. We as humans can rely on the constancy that is elemental to God's

100. Al-Ghazali, supra n. 77, at 162-163 (emphasis added). 
grace, and fuse fact and value to create legal norms through a rational assessment of empirical reality. But we are also aware that God can alter His grace if He chooses.

\section{NATURAL RIGHTS IN ISLAMIC LAW: A FRAMEWORK FOR DiSCRETION}

Jurists did more than theorize in the abstract about the use of juristic discretion and the need for determinacy amidst interpretive freedom. Positivists and Mu'tazilites could not escape a reliance on juristic discretion to determine the law. But to discuss discretion at the theoretical level does not necessarily indicate that jurists used discretion in creating specific rules of law. However, as shown below, jurists utilized discretion in creating specific rights regimes in ways that also evinced their concem with providing at least a limited determinacy in the face of individual interpretation. They provided limited determinacy by relying on cercain foundational principles by which they could distribute rights and entitlements across society. These principles provided a base level of determinacy and objectivity to the use of juristic discretion.

These foundational principles, though, are not always explicit or express in the textual sources. Rather they are gleaned from the rationales jurists provided for the rules they created. In some instances, the foundation of a right depended on some inherent conception of the individual and his nature. In other cases, the foundation of a right or liability depended on an overarching conception of the kinds of commitments we make to society as participants in a common endeavor. And still again, the foundation of a right may be based on a conception of the good that balances the needs of individuals with the commitments we make to society. Fundamentally, the premodem juristic concem with foundations seems to have involved an underlying theoretical concern with the use of discretion and the need to provide predictable results and at least a limited determinacy in the law. As will be shown below, jurists seem to have relied on certain conceptions of the individual and the social good that they gave expression through the law to determine both rights and duties in a way that utilized discretion but avoided radical indeterninacy.

The term used in Arabic for right is haqq. Premodern Arabic lexicographers provided a complex definition of this term. On one hand it can refer to the certainty or truth (yagin) of a matter, and is an antonym for falsehood (batil). ${ }^{101}$ When it is used with the definite article

101. Ibn Manzur, supra n. 49, at 10:49-50, 52; Abu Fayd Muhammad Murtada al-Husayni al- 
(al), al-haqq is a name for God (The Truth). ${ }^{102}$ It can also refer to property, justice, and that which wisdom or prudence brings about ( $l i$ mujid al-shay' bi hasab ma taqtadihi al-hikma). ${ }^{103}$ But what is most compelling in the definition of the term haqq is the fact that lexicographers related that the Arabs often would say haqq invokes "that which I must do" (haqq 'alayya an af'ala dhalik). ${ }^{104}$ In other words, when one says "there is a haqq on you to do X" (haqqa "alayka an taf'ala), he means that "you are obligated" to do X (wa jaba 'alayka). ${ }^{105}$

Certainly, haqq refers to a duty. But underlying this definition is an ambiguity as to whose interest is served by satisfaction of that duty. One may be obligated to do something, but for whom? The interest served may be a private one but in other cases it may be a public one. When the interest is private, the term "right" seems a suitable definition for the term haqq. By using the term "right" to capture the meaning of haqq in haqq al-'ibad or the right of individuals what is intended is to embrace the complex of interests that individuals hold when participating as members of society. Whether these are interests in freedom from interference (liberty interests), or interests that assert an entitlement (claim interests), the term haqq seems to capture them both by simultaneously asserting an obligation on one person and creating a claim in another. ${ }^{106}$

But in the case of the huquq Allah or public interests, the term "right" in the phrase "right of God" seems inappropriate. The huquq Allah do not fundamentally invoke specific litigable individual interests. Rather, as shown below, the govemument has the duty to uphold such public interests on behalf of society. The government's imperium places upon it the responsibility to effectuate the public interest through its legal and punitive instrumentalities. The huquq Allah seem to reflect an understanding of a vision of some common good or public welfare interest. Consequently, the use of "right" to translate the phrase huquq Allah into "rights of God" seems inapt and misleading at first. However,

Zabidii, Taj al-'Unus min Jawahir al-Qamus 13:80 (Dar al-Filer 1994); E.W. Lane, Arabic-English Lexicon 1:607 (Isłamic Texts Socy. 1984).

102. Ibn Manzur, supra n. 49, at 10:50; Murtada al-Zabidi, supra $\mathrm{n}$. 101, at 13:79.

103. Murtada al-Zabidi, supra $\mathrm{n}$. 101, at 13:79-80.

104. Ibn Manzur, supra n. 49, at 10:51; Murtada al-Zabidi, supra n. 101, at 13:81; Lane, supra n. 101 , at 1:605.

105. Murtada al-Zabidi, supra n. 101, at 13:81, 82.

106. For a discussion of the different kinds of claims captured by the term "right," see Wesley Newcomb Hohfeld, Fundamental Legal Conceptions as Applied in Judicial Reasoning (Walter Wheeler Cook ed., repr. ed., Yale U. Press 1964) (originally published 1919). For a discussion of Hohfeld's typology of rights see John Finnis, Natural Law and Natural Rights 199-205 (tcpr. ed., Clarendon Press 1993) (originally published 1980). 
because jurists generally associated the rights of God with the public interest as vested in the govemment itself, I utilize the phrase "rights of God" as a technical term of art to represent a public policy interest that must be effectuated by the government, given its presumed exclusive authority and power over the mechanisms of violence and compulsion.

The ambiguity as to whose and what interest is served by the hagq may help us understand the discretionary dynamics that premodern jurists engaged in when devising rules of law, and distributing rights across society amidst competing interests. The rights of God were deemed to address the public interest, whereas the rights of individuals spoke to personal interests. Using this heuristic, jurists arguably distributed rights by balancing the competing substantive interests posed by the needs of the community and the needs of the individual through the discretionary creation of rules of law. They both gave substance to these conceptions and balanced them to reach a result that was not arbitrary and subject to undisciplined speculation.

\section{Case Stiddy: Petitioning in a Case of Slander}

A case where the rights of God and rights of individuals heuristic balanced competing interests is in premodern discussions on the crime of slander of fornication/adultery, or qadhf. In Islamic criminal law, certain punishments are elaborated in the Qur'an, and as such they are considered explicitly articulated and defined by God. These are called the hudud crimes (sing. hadd). Slander is one such crime. Specifically the Qur'an states:

And [concerning] those who level a charge against chaste women and do not bring four witnesses, whip them eighty lashes and do not accept their testimony ever, for they are corrupt, except for those who repent thereafter and act righteously. Indeed God is forgiving and merciful. ${ }^{107}$

In the premodern juristic literature, debate raged as to whether the hadd for qadhf, or punishment for slander, is intended to uphold a right of God or a right of individuals. As will be shown below, the punishment for slander was eighty lashes, and the question troubling jurists was in determining whom this single liability benefits, God or the victim, the public or the individual. To answer this question, the jurists engaged in many specific, technical debates concerning pleading requirements and the rights of the victim in the litigation process as will be discussed below. Fundamentally, underlying the debates is a contest

107. Qur'an 24:4-5. 
over defining the purpose of the penalty and the good it seeks to effectuate. And by arguably relying on contextual conceptions of the individual and the social good, the jurists seemed to be searching for a foundation to justify their rights distribution schemes to provide a degree of determinacy to their discretionary rulings.

Much of the debate arose out of a concern over what good is achieved from the punishment for qadhf. On one hand, it deters people from engaging in slander, which is a public good; on the other hand it affects retribution for an attack on a specific person's dignity and honor, thus vindicating a personal interest. The more a jurist focused on the deterrent effect of the punishment and its effort to rid the world of evil, the more he likely saw the sentence of slander as upholding a right of God. One of the underlying purposes of the rights of God, such as those underlying the hudud penalties, is to achieve a sense of social welfare and benefit through deterrence (zajr or inzijar). ${ }^{108}$ The deterrence function of the punishment of slander was seen as supporting the public good and hence was considered a right of God. For instance, the Hanafi jurist Badr al-Din al-'Ayni (d. 855/1451) held that if viewed as a public right, or as he called it a hagq al-shar', the punishment for slander is to rid the world of corruption (ikhla' al-'alam 'an al-fasad). In this sense, the punishment invokes a right of God since it does not pertain to any one person, but is in the interests of the general society. ${ }^{109}$ It maximizes social good by deterring people from an evil that may adversely affect

108. Abu Muhanmad 'Abd Allah b. Ahmad b. Muhammad b. Qudama (Hanbalite, d. 620/1223), al-Mughni 8:299 (Dar Ihya’ al-Turath al-'Arabi n.d.); Mansur b. Yunis al-Bahuti (Hanbalitc, d. 1051/1641), Kashshaf al-Qina' 'an Matn al-Iqna' 6:109 (Abu 'Abd Allah Muhammad Hasan Muhammad Hasan Isma 'il al-Shafi'i ed., Dar al-Kutub al-'Ilmiyya 1997); Taqi al-Din Ibn Taymiyya (Hanbalite, d. 728/1328), al-Siyasa al-Shar'iyya fi Islah al-Ra'i wa alRa'iyya 90 (Dar al-Kutub al-'Ilmiyya, 1988); Al-Marghinani (Hanafite, d. 593/1197), supra n. 43, at 1-2:381, 402; Zayn al.Din b. Ibrahim b. Muhammad Ibn Nujaym (Hanafite, d. 970/1563), alSharh al-Bahr al-Ra'iq 5:4 (Zakariya 'Amirat ed., Dar al-Kutub al-'IImiyya 1997); Mahmud b. Ahmad b. Musa b. Ahmad b. al-Hasan Badr al-Din al-'Ayni (Hanafite, d. 855/1451), al-Binaya Sharh al-Hidaya 6:371 (Amin Salih Sha'ban ed., Dar al-Kutub al-'Ilmiyya 1999); Abu al-Hasan 'Ali b. Muhanmad b. Habib al-Mawardi (Shafi'ite, d. 450/1058), al-Hawi al-Kabir 13:367 ("Ali Muhammad Mu'awwad and 'Adil Ahmad 'Abd al-Mawjud ed., Dar al-Kutub al-'llmiyya 1994).

109. Badr al-Din al-'Ayni, supra n. 108. For others who held a similar view about the role of the huquq Allah in generally ridding the world of corruption for the betternent of society, see Ibn Nujaym (Hanafite), supra n. 108; Muhammad b. 'Abd Allah b. 'Ali al-Khurashi (also, alKharashi) (Malikite, d. 1101/1690), Hashiyal al-Khurashi 'ala Mukhtasar Sayyidi Khalil 8:329 (Zakariyya 'Umayrat ed., Dar al-Kutub al-'Ilmiyya 1997); al-Marghinani, supra n. 43, at 1-2:402; Salih 'Abd al-Sami' al-Abi al-Azhari, Jawahir al-lklil 2:437 (Muhammad 'Abd al-Aziz al-Khalidi ed., Dar al-Kutub al-'Ilmiyya 1997). The Malikite jurist al-Sahnun (d. 240/854) wrote that where a non-Muslim resident or dhimmi steals, the Qur'anic penalty of theft must be applied and his hand cut of $f$ because the harm posed is a general evil (jasad $f i$ al-ard), thus speaking to the public welfare interest underlying this penalty. Sahnun b. Sa'idal-Tanukhi (d. 240/854), al-Mudawwana al.Kubru 6:270 (Dar Sadiur n.d.). 
the common welfare of society.

A right of individuals, on the other hand, satisfies someone's personal interests. In the case of slander, one interest at stake is the victim's dignity and honor $\left.\left(a^{\prime} \mathrm{rad}\right)\right)^{110}$ The more one understands the penalty of slander to vindicate a person's honor and dignity, the more one is likely to view the right at stake as being a personal, individual right-a hagq al- 'abd. In fact, the Shafi' ite jurist and judge al-Mawardi (d. 450/1058) believed that honor is something integral to each person, like his physical well-being and property. He wrote: "What is invoked in the case of [injuries to our] physical well being and property are personal rights, and so too in the case of [in juries to our] dignity" (kana ma wajaba fi al-dima' wa al-amwal min huquq al-adamiyin, fa kadhalik ma wajaba fi al-a'rad). ${ }^{1 \prime \prime}$ Whether the punishment of slander is a right of God or a private right, therefore, depends on how one understands the purpose underlying the sanction. What good does it seek to vindicate and for whose interests, the public's or the victim's?

The impact of this debate about whether the punishment of slander is a right of God or a right of individuals af fects various issues in the area of pleading and litigation. The rights of the plaintiff to initiate his case, to have it prosecuted, and to ultimately waive the infraction all depend on whether one views the punishment of slander to invoke a right of God or a right of individuals. The more it embraces a right of God, the less discretion the individual claimant will have in prosecuting his case, and the more the government will play a dominant role in redressing the wrong in the interests of the public good. If, on the other hand, it is a private right, the plaintiff will have greater flexibility in whether and how he presses his claim against the defendant. Jurists writing in all the four Sunni schools of law raised these pleading and litigation questions, and in doing so, they ultimately balanced the competing interests at stake. For instance, must the plaintiff petition the authorities for redress? In other words, suppose defendant D slanders plaintiff $\mathrm{P}$ and $\mathrm{P}$ never brings a petition for redress. But $\mathrm{W} 1$ and $\mathrm{W} 2$ witnessed the slander. Can the state prosecute D on the testimony of W 1 and W2 without a petition from P? Suppose the right is a right of God and $\mathrm{P}$ must petition. If $\mathrm{P}$ fails to petition, does that mean $\mathrm{P}$ can

110. Badr al-Din al-'Ayni, supra n. 108; al-Mawardi, supra n. 108, at 11:10; Abu 'Abd Allah Muhammad b. Ahmad al-Qurtubi, al-Jami' li Ahkam al-Qur'an 12:116 (Dar al-Kutub al-'Ilmiyya 1993); al-Marghinani, supro n. 43, at 1-2:400, 402. In fact, the Malikite jurist Abu Bakr b. al'Arabi (d. 543/1 148), argues that God considers upholding one's honor and dignity so important that nearly one-third of all prohibitions protect one's integrity ( $a$ 'rad). Abu Baks b. al-'Arabi, Kitab al-Qabas 3:1 18 (Muhammad 'Abd Allah Walad Karim ed., Dar al-Gharb al-Islami 1992).

111. Al-Mawardi, supre n. 108, at 11:10. 
effectively negate a right of God? If rights of God are supposed to benefit society, does any requirement to petition unduly empower $P$ with an authority to undermine social well-being if he chooses not to petition? Alternatively, if the right is a private right, can the state prosecute D without $\mathrm{P}$ 's presence or petition? What if $\mathrm{P}$ is embarrassed by the situation and wants the case to disappear to protect his already attacked honor? If the right is an individual right, then $P$ should have the right to decide if the case proceeds or not.

To illustrate the balancing at stake when distributing rights, I will focus on the issue of petitioning in a slander case. Among the Sunni schools of law, the Shafi'ite school tended to view the punishment of slander as predominantly a haqg al-'abd or a right of individuals. ${ }^{112}$ This is in large part reflected by the fact that they required the plaintiff to petition for the punishment before the political authority would carry it out. In other words, they did not permit a case to be prosecuted only where there are witnesses who observed the slander and later testified before a court. The government cannot apply this sentence without the injured party first raising the issue, and voicing his or her desire for redress. For jurists such as al-Mawardi (d. 450/1058), the petition requirement underscored the fact that the interest at issue is predominantly a personal right, and not a right of God. If it were a right of God, he suggested, no petition would be required. ${ }^{113}$

For other Shafi'ite jurists such as Yahya b. Sharaf al-Nawawi (d. $676 / 1277$ ) the right at stake is mostly a private right, but he admitted that there is some reason for calling it a right of God. For instance, the punishment for slander is eighty lashes for a free person. But if the perpetrator is a slave, the penalty is halved. For al-Nawawi, from the perspective of the victim, whether the perpetrator is fiee or a slave should not matter. What matters is that the victim's right has been violated. The reason the punishment is halved, therefore, must reflect an interest of God's, thereby suggesting that the punishment of slander is not simply an individual right but includes some components of a right of God. Nevertheless, al-Nawawi argued that despite the fusion of both rights in the same penalty, the right at stake is mostly a personal right since the victim must first file a petition in order to seek redress and can waive the violation if he so chooses. ${ }^{114}$

112. Abu Bakr lbn al-'Arabi, supra n. 110, at 3:1019; Abu Bakr Muhammad h. Ahmad alQaffal al-Shashi, Hilyat al-'Ulama' fì Ma'nifa Madhahib al-Fugaha' 8:40 (Yasin Ahmad Ibrahim Daradakah ed., Maktabat al-Risala al-Haditha 1988).

113. Al-Mawardi, supra n. 108, at 11:10.

114. Yahya b. Sharaf al-Nawawi, Rawdat al-Talbin wa Umdat al-Muftin 10:106-107 (3 $3^{\mathrm{d}} \mathrm{ed}$, 
The Hanbalites adopted the same position as the Shafi'ites. The Hanbalite jurist Abu Ishaq Ibn Muflih (d. 804/1401) said that the most obvious and popular view among the schools (al-azhar wa al-ashhar) is that the right at stake is a private one since it can be waived by the victim if he desires. ${ }^{115}$ Both Ibn Qudama (d. 620/1223) and Abu alHasan al-Mardawi (d. 885/1480) held that a petition is required to satisfy the right, which both agree is a right of individuals. ${ }^{116}$ According to Mansur b. Yunis al-Bahuti (or al-Buhuti) (d. 1051/1641), in order to implement the penalty of slander, the victim is required to petition the government. The petition must remain in force until the punishment is applied and there should be no waiver of the right. ${ }^{117}$ The case of slander differs, for instance, from the case of fornication (zina). According to Ibn Qudama, no petition is required for a case of fornication or adultery because the penalty involves purely a right of God. In other words, the government can raise the case on its own against one who has engaged in illicit sex. The right underlying the fornication punishment, he argued, does not invoke any private interests, and effectively belongs solely to God. ${ }^{118}$ Notably, the later Shafi'ite jurist 'Ali b. 'Ali al-Shabramallisi (d. 1087/1676) stated that a husband has a right against the man fornicating with his wife. What this right entails, though, he did not explain. But what seems evident from this minor debate is how a matter of pleading can reflect larger concerns and

al-Maktab al-Islami 1991). For other Shafi'ite jurists who considered the punishment of slander to be a right of people and require a petition for redress, see Abu Ishaq Ibrahim b. 'Ali h. Yusuf alShirazi (d. 476/1083), al-Muhadhdhab fi Figh al-Imam al-Shafi'i 3:349 (Zakanya al-'Amirat ed., Dar al-Kutub al-'Ilmiyya 1995); Fakchr al-Din al-Razi (d. 620/1209), al-Tafsir al-Kabir 8:327 (3 ed., Dar lhya' al-Turath al-'Arabi 1999). The Malikite Ibn Rushd al-Hafid (Averroes, d. 595/1198) remarked that for the Shafi'ites, even if the victim petitions the authority for the punishment, he can still decide to forgive and waive the offense thereafter. Abu al-Walid Muhammad b. Ahmad b. Muhammad b. Ahmad Ibn Rushd al-Hafid, Bidayat al-Mujtahid wa Nihayat al-Mugtasid 2:647-648 ("Ali Muhammad Mu'awwad \& 'Adil Ahmad 'Abd al-Mawjud eds., Dar al-Kutub al-'IImiyya 1997).

115. Abu Ishaq Ibrahim b. Muhammad b. 'Abd Allah b. Muhammad Ibn Muflih, al-Mubdi' $f i$ Sharh al-Muqni' 9:84 (al-Maknb al-l slami 1979).

116. Abu Muhammad 'Abd Allah b. Ahmad b. Muhammad Ibn Qudama, al-Mughni 8:217 (Dar lhya' al-Turath al-'Arabi n.d.); Abu al-Hasan 'Ali b. Sulayman h. Ahmad al-Mardawi, alInsaf $f i$ Ma'rifa al-Rajih min al-Khilaf 'ala Madhhab al-Imam Ahmad b. Hanbal 10:185 (Abu 'Abd Allah Muhammad Hasan Muhammad Hasan Isma'il al-Shafi'i ed., Dar al-Kutub al-'llmiyya 1997).

117. Mansur b. Yunis al-Bahuti, Kashshaf al-Qina' 6:134 (Dar al-Kutub al-'Ilmiyya 1997). Interestingly, Abu 'Abd Allah Muhammad Ibn Muflih (d. 763/1362) said that even those who considered the punishment of slander to be a right of God still required the victim to file a petition. Abu 'Abd Allah Muhammad Ton Múlih, al-Furu' 6:96 (Abu al-Zahra' Hazim al-Qadi ed., Dar a!Kutub al-'Ilmiyya 1997). As will be illustrated below, this is the Hanafite position.

118. Ion Qudama, supra n. 116, at 8:284-285. 
conceptions about rights and entitlements across society. ${ }^{119}$

The Malikite position best reflects the underlying tension in defining the punishment of slander as a right of God or a private right. Generally, the Malikites argued that the penalty of slander presents a mixed right, where both the right of God and the right of individuals are implicated. For instance, the Malikite jurist Abu Bakr Ibn al-'Arabi (d. 543/1 148) recognized that there were two views on whether the right is a right of God or a private right. The debate, he suggested, arose among the schools of law because the underlying crime violates both sets of rights. But for him, the crime invokes largely a private right because, in part, the right is contingent on the victim filing a petition. The political authority can carry out the penalty only if a petition (mutaliba) has been filed. ${ }^{120}$ But because the Malikites attempted to take a middle position, they also imposed limitations on the plaintiff in order to effectuate the interests underlying the right of God component of the crime. Specifically, after the crime has occurred but before it is petitioned to the government, the right that is implicated is an individual right. Consequently, the victim has the right to petition for redress or waive his rights. Once he petitions for redress, though, the victim can no longer waive his rights. After the petition has reached the governing authority, the right transforms from being a private right to a right of God, and as such, the political authority must carry out the prosecution and punishment. $^{121}$ Nevertheless, the Malikites still tried to preserve the individual's rights even after the matter reaches the political authority. In some limited cases, where the victim does not want the publicity of the case, and instead prefers the matter be removed from public view (sitr), he can still waive his rights even after the courts have begun hearing the matter. ${ }^{122}$ This exceptional ruling applies to the situation where the claim is brought by those other than the victim. For instance, suppose two witnesses observed the slander and filed a claim with the political authority. ${ }^{123}$ In this case, the Malikites did not require a petition by the victim and instead allowed others to bring the case; but they did

119. 'Ali b. 'Ali al-Shabramallisi, Hashiya 'ala Nihayat al-Muhtaj, in the margins of Muhannad b. Abi al-'Abbas Ahmad b. Hamza b. Shihab al-Din al-Ramli al-Shafi'i al-Saghir, Nihayat al-Muhtaj ila Sharh al-Minhaj 7:423 (Dar Ihya' al-Turath al-'Arabi 1992).

120. Abu Bakr Muharmad b. 'Abd Allah Ibn al-'Arabi, Ahkam al-Qur'an 3:1335-1336 ('Ali Muhammad al-Bajawi ed., Dar al-Ma'rifa n.d.).

121. Al-Qaffal, supra n. 112; Abu al-Walid Muhammad b. Ahmad Ibn Rushd (al-Jadd) (d. 520/1126), al-Muqaddimat al-Mumahhidat 3:266 (Muhammad Hujji ed., Dar al-Gharb al-Islami 1988); Ibn Rushd al-Hafid, supra n. 114, at 2:647-648. Al-Khurashi, supra n. 109, at 8:308.

122. Ibn Rushd al-Jadd, supra n. 121.

123. According to the Shafi'ite al-Mawardi, this was an option allowed by the Malikites. AlMawardi, supra n. 108, at 11:9. 
permit the victim to dissolve the case after it has reached the courts. ${ }^{124}$ This approach balances the public and private aspects of this crime. The public evil is so broad as to grant others standing to bring a claim without the victim present. But it is not so broad as to deny the victim the right to shield himself from further embarrassment by a public proceeding.

Among the Hanafites, the dominant view was that the punishment of slander represented a right of God. ${ }^{125}$ This was the position held by Abu Hanifa (d. 150/767), the eponym of the Hanafite school of law. Notably, Abu Hanifa required the victim to file a petition but did not allow the claimant to waive the claim, the latter requirement being what made the right a right of God. ${ }^{126}$ Others, such as the earlier jurist and Successor (Tabi') al-Hasan al-Basri (d. 110/728) argued that the penalty is a pure right of God, and as such, no petition by the victim was required. ${ }^{127}$ It seems that for al-Basri, since the evil at issue is a public evil, the victim is not the only one who has the right to press the claim. In fact, later jurists associated this general grant of standing with the Hanafites. As the Malikite jurist Ibn Rushd al-Jadd (d. 520/1126) stated, since the Hanafites demanded that the punishment of slander be applied without any discretionary determinations by the victim, it followed that the political authority applies the punishment when the charge is brought by any member of the public (bi qiyam man qama bihi min al-nas). ${ }^{128}$

However, this description of the Hanafite position does not quite explain Abu Hanifa's demand for a petition by the victim. To suggest that the claim could rise and fall on the basis of a claimant's petition would render the right at issue an individual right and not a right of God, or alternatively would allow a right of God to fall for reasons of a private and personal nature. Abu Hanifa's position, recognizing the right as a right of God but requiring a petition, presents a difficult compromise between the tensions underlying the private and public nature of the act of slander. Without the petition, no case could be heard, despite the fact that for the Hanafites, the evil at issue was a public one that threatened society at large and did not pose a solely

124. Ibn Rushd (al-Jadd), al-Bayan wa al-Tahsil 16:290 (Ahmad al-Hababi ed., Dar al-Gharb al-Islami 1988).

125. Shams al-Din al-Sarakhsi, Kitab al-Mabsut 9:105 (Dar al-Kutub al-'Ilmiyya 1993); Jbn al-'Arabi, supra n. 110, at 3:1019; al-Qurtubi, supran. 110, at 12:118.

126. Abu Bakr Ahmad b. 'Ali al-Jassas, Ahkam al-Qur'an 3:352 ('Abd al-Salam Muhammad 'Ali Shahin ed., Dar al-Kutub al-'Ilmiyya 1994). See also al-Qaffal, supra n. 112; al-Mawardi, supra n. 108, at 11:9.

127. Al-Qaffal, supra n. 112; al-Mawardi, supra n. 108, at 11:9.

128. Ibn Rushd (al-Jadd), supra n. 124. 
personal violation of rights. Furthernore, later Hanafites, such as Ibn Nujaym (d. 970/1563), required the victim to be present when the actual punishment is inflicted. ${ }^{129}$ To view the right as a right of God yet require both a petition to be filed and the victim to be present seems contradictory at first blush. In fact, the Andalusian jurist Ibn Hazm (d. 456/1063) noted that the Hanafite position, which considers the right a right of God but requires a petition, is inconsistent. ${ }^{130}$ The Hanafite jurist, al-Kasani (d. 587/1191), recognizing this potential incongruity, held that the requirement of a petition does not vitiate the fact that a right of God is at stake. Rather, the petition requirement satisfies procedural requirements conceming the mechanism of litigation. But it does not affect the substantive quality of the right at stake. ${ }^{131}$

Abu Hanifa's disciple Abu Yusuf (d. 182/797) is reported to have held a different view from his teacher. Abu Yusuf considered the punishment of slander a mixed right (haqq mushtarak). Consequently, he required a petition to be filed by the victim, and even allowed the victim to waive his rights, but only before the case reached the political authority. ${ }^{132}$ The later Hanafi al-Marghinani (d. 593/1 197) also believed that the right is a mixed right. For him, the issue centered on whether one emphasizes the individual right more or less than God's right. He held that the dominant right is that of God, and consequently, while he required a petition, he did not allow the right to be heritable for instance. ${ }^{133}$

To summarize, the debate above presents a technical inquiry into the petition requirement for a case of slander. The Shafi'ites and Hanbalites required the victim to petition before the penalty of slander would be applied. This requirement, according to many of them is what made the right at stake a right of individuals. The case is contingent on the individual asserting a right that arguably expresses a shared commitment concerning his entitlements. If there is no petition, there is no case and no punishment is meted out against the defendant. This is a classic position of those who adhered to the view that the punishment of

129. Ibn Nujaym, supra n. 108, at 5:61.

130. Abu Muhammad 'Ali b. Ahmad b. Sa'id Ibn Hazm, al-Muhalla bi al-Athar 12:256 ('Abd al-Ghaf ar Sulayman al-Bandari ed., Dar al-Kutub al-'llmiyya n.d.).

131. 'Ala' al-Din Abu Bakr b. Mas'ud al-Kasani, Bada' 'i' al-Sana 'i' fi Jartib al-Shara'i' 9:249 ('Ali Muharnmad Mu'awwad \& 'Adil Alunad 'Abd al-Mawjud eds., Dar al-Kutub al-'Ilmiyya 1997).

132. Al-Qaffal, supra n. 112; al-Mawardi, supra n. 108, at 11:9. The Hanafite jurist alSarakhsi suggested that Abu Hanif a's other disciple, Muhamonad b. al-Hasan al-Shaybani (d. 189/805) also held the view ascribed to Abu Yusuf. Al-Sarakhsi, supra n. 125, at 9:107.

133. Al-Marghinani, supra n. 43, at 1-2:402. 
slander poses a violation of a dominantly individual interest. The crime at its heart is an infraction against the individual, where attacks on dignity and honor are best seen as an individual affair.

On the other hand, the Malikites attempted to balance the individual and public interests in a case of slander through, in part, the petition requirement. First, they allowed the possibility of a case being brought by someone other than the victim. Second, they asserted that prior to filing the petition, the right at stake is a private right. But once a petition is filed and govermment machinery is invoked, the public takes an interest in the outcome. The case is no longer about the victim's personal rights, but rather reflects the public's interest in upholding the values of honor and dignity, which are not simply individual affairs. Yet, in those cases where the petition is brought by those other than the victim, the victim has the option to def eat the prosecution. Hence while the dignity interests at stake reflect larger public concerns, the Malikites did not lose sight of the fact that this crime involves a personal stake in one's dignity.

The public interest in honor and dignity is perhaps best represented by many Hanafites who considered the punishment of slander a right of God. For them, the virtues at stake were those that pertained to society at large. While the attack is clearly on one's individual dignity and honor, the right to enforce and uphold such values does not reside in the individual but rather belongs to the public through the governing authority. While the Hanafites nonetheless required the victim to file a petition to have the case heard, they considered the petition to be virtually a neutral procedural requirement for upholding the right of God.

The debates illustrate that the jurists were doing more than specifying technical issues of litigation procedure. Arguably, they were utilizing their discretion over the law to create rules of pleading which manif ested contested meanings of dignity, which they implicitly utilized to give limited determinacy to their use of discretion. The fact that the Qur'an specifically identifies this infraction and specifies an exact punishment renders this crime significant in ways that other possible crimes are not. Perhaps these jurists believed that God singled out this crime, and in doing so, intended to articulate a social value that transcends the individual and his entitlements, and speaks to a larger value to which society at large must aspire. The challenge for the jurists was how to balance the interests of the individual with the social interests that seem to be invoked by the Qur'an in a way that was not random, but which nonetheless required juristic discretion given the lack 
of scriptural guidance on the matter. When jurists used the heuristic of the rights of God and the rights of individuals, they were attempting this substantive and discretionary balance. The different outcomes among the schools did not reflect simply basic disagreements in reading scriptural text. In fact, when discussing the petition requirement, jurists did not actually invoke scripture at all. Rather, it seems that underlying debates such as those on petitioning was a contest concerning the competing conceptions that jurists of a particular school held on the individual, his society, and the relationship between the two.

\section{CONCLUSION}

The prevailing historiography on Islamic law perpetuates a scriptural positivism characteristic of an inherited Islamic orthodoxy, while at times illustrating how premodern jurists struggled to infuse some flexibility into a system that was otherwise beset by the positivist presumptions of textual authority. ${ }^{134}$ The ability to look to indices besides scripture was hotly contested among premodern Muslims, as it is among today's Muslims along the modemist and fundamentalist spectrum.

By focusing on the natural law and natural rights traditions in Islamic law, I argue that jurists writing in the Sunni Islamic legal tradition were immersed in a context of controversy and debate over the appropriate role of extra-scriptural indicators, such as reason and nature, in the process of determining the law of God. Mu'tazilite naturalist jurists like al-Jassas asserted that reason can deternine divine obligations where scripture is silent. To justify his use of reason, alJassas relied on a natural teleology as a foundation to tie his use of reason to a search for the divine will through the medium of nature.

Positivist jurists opposed any such role for human reason. Relying on a divine command theory of ethics, they argued that divine obligation must be based on scripture. In the absence of scripture, one is left in an epistemic state of suspension. And while Positivist jurists agreed that humans can and do make moral decisions all the time, they denied that

134. For works that accept the positivist description of Islamic law, see for instance, Joseph Schacht, An Intreduction to Islamic Law (repr. ed., Oxford U. Press 1997) (originally published 1964); N.J. Coulson, A History of Islamic Law (repr. ed., Edinburgh U. Press 1997) (originally published 1964); Bemard G. Weiss, The Spirit of Islamic Law (U. Ga. Press 1998). For studies that attempt to identify some theoretical flexibility in a legal system otherwise beset by scriptural positivism, see Wael B. Hallaq, Authority, Continuity and Change in Islamic Law (Cambridge U. Press 2001); Yasin Dutton, The Origins of Islamic Law: The Qur'an, the Muwatta', and Madinan Amal (Curzon 1999). 
such decisions could have the force of a divine obligation.

Nevertheless, as illustrated by al-Ghazali's discussion on maslaha, even Positivist jurists relied on a naturalistic argument to provide a foundation for their use of discretion where scripture is otherwise silent. But Positivist naturalism was softer than Mu'tazilite naturalism in that it was not based on a rationally derived natural teleology that provided a persistent foundation for inquiry. Rather, Positivists like al-Ghazali tried to balance the need for a naturalistic justification for discretion with the desire to maintain a theology of God's voluntarism and omnipotence. Consequently, their naturalism, as illustrated by the discussion on al-Ghazali, was based on a textual foundation and the notion of God's grace. Scripture provided the normative basis for rendering nature value-laden, while God's grace preserved God's everlasting omnipotence. For Positivists like al-Ghazali, nature was certainly beneficial. But that benefit was due to God's grace, which could change were God to change His mind. Whereas al-Jassas' naturalism embraced a sense of nature that yielded persistent benefits in a way that effectively seemed to impose an obligation on God to do the good, al-Ghazali's naturalism preserved God's voluntarism, while utilizing nature as a foundation for objectifying and nornativizing the products of juristic discretion.

Discretion therefore has a theoretical foundation in the usul al-figh literature. But more than just a topic of abstract theoretical analysis, discretion played a role in the actual determination of legal rules where scripture seemed to be silent. By relying on the heuristic device of the rights of God and rights of individuals, premodern jurists arguably incorporated extra-scriptural inquiries conceming the nature of the individual and conception of the social good into their juristic inquiry to inform the law and infuse it with limited determinacy.

To illustrate how this conceptualization of juristic discretion along naturalistic lines seems particularly relevant to contemporary debates on Islamic law, a final example will suffice. Recently, news reports from Ontario, Canada suggest that the province may implement Shari'a arbitration panels for Muslims to seek resolution in matters of marriage, divorce and inheritance pursuant to Islamic law. In her report, Marion Boyd argues that such a panel would rely on "Islamic principles" to determine and decide cases. ${ }^{135}$ What these principles are, however, is left entirely ambiguous. Are these principles reflective of historical

135. See Marion Boyd, Dispute Resolution in Family Law: Protecting Choice, Promoting Inclusion. Section I: Introduction and Structure (available at http://www.attomeygeneral.jus. gov.on.ca/english/about/pubs/boyd/fillreport.pdf (accessed Oct. 2005)). 
precedent or the consensus of premodern jurists (ijma') on aspects of marriage and divorce law? Are they principles such as the al-qawa'id al-fighi yya, which are interpretive presumptions that guide legal analysis where scriptural texts are less than clear, or that resolve conflicts between competing evidence? In the end, this phrase is unclear and largely meaningless.

To understand the dilemma this phrase presents, and the general challenges that the arbitration panel will face, if it is implemented, an example from premodem divorce law will suffice. Under the premodem Islamic law of divorce, a husband had the unilateral, unrestricted right to divorce his wife without recourse to court adjudication (i.e., talaq), while a woman had to petition a court to obtain a divorce. A wife could seek either a for-cause divorce or a no-cause divorce. In a for-cause divorce, she alleged some fault on the part of her husband (e.g. failure to support, abuse, impotence) and sought a divorce while preserving her financial claims against her husband. In a no-cause or khul' divorce, a woman asserted no fault by her husband, and agreed to forgo any financial claim against her husband to regain her freedom from the marriage. ${ }^{136}$ The difference between a husband's right of divorce and a wife's right was fundamentally a matter of the degree and scope of the power to assert one's liberty interests. A premodern talaq divorce allowed the husband to avoid any court involvement. He simply pronounced to his wife that she was divorced. He was subjected to limited maintenance for a specified period of time thereafter. The wife's power of divorce was a more limited power that restricted a wife's freedom to divorce by subjecting her to court oversight and, in the nofault option, imposed upon her a duty to forf eit her financial claims against her husband. Arguably, the husband's power was a greater power, whereas the wife's power to seek divorce was much more restricted.

According to the premodern Shafi'ite jurist al-Mawardi (d. 450/1058), the husband's unilateral power to divorce was based, in part, on a Qur'anic verse which reads: "O Prophet, when you divorce women,

136. For discussions on this distribution of rights scheme conceming the right of divorce, see Susan Spectorsky, Introduction, in Chapters on Marriage and Divorce: Responses of Ibn Hanbal and Ibn Rahwayh 27-39, 50-52 (Susan Spectorsky trans., U. Tex. Press 1993); Haifaa A. Jawad, The Rights of Women in Islam: An Authentic Approach 79-82 (St. Martin's Press 1998). For a survey of how modem Muslim states deal with divorce right schemes, see Abd Allah Abmad Na'im, Islamic Family Law in a Changing World: A Global Resource Book (Abdullahi A. AnNa'im ed., Zed Books 2002). Notably, a woman may reserve for herself in her marriage contract the power to unilaterally divorce her husband. But this must be negotiated with her husband, and is not the default position. 
divorce them at their prescribed periods." ${ }^{\text {"137 }}$ One might ask why should men be given the unilateral right to divorce their spouses to the exclusion of women? Why not read this verse as a procedural mechanism rather than a grant of substantive right? In other words, one could argue that both men and women have the right of unilateral divorce, but that it must be used in a manner that accords with certain procedural protections outlined in this verse. But this was not the reading given to this verse. For instance, according to al-Mawardi, although this verse is directed to the Prophet specifically, it actually has a general import and is applicable to all Muslims. ${ }^{138}$ The question for alMawardi was whether the substantive right of divorce implied by this verse extends only to men or to women as well. He said that the talaq right vests only in husbands and is solely applied against wives (al-talaq la yasihhu illa min zawj wa la yaqa'a illa 'ala zawja). ${ }^{139}$ Husbands are the sole recipients of this right, despite the fact that both husband and wife participate and join in the contract of marriage together ('agd alnikah). ${ }^{140}$ According to al-Mawardi, this distinction is based on the fact that the Qur'an provides that men have a degree of superiority over women (wa li al-rijal 'alayhinna daraja). ${ }^{141}$ Despite the Qur'anic verse, al-Mawardi nonetheless recognized the disparity in the distribution of the talaq right of unilateral divorce. But he explained that disparity as follows. First, since the duty to provide support and maintenance (mu'una) falls exclusively on the husband, the husband is entitled to certain special rights given this difference (jaza an yukhtassu al-zawj bi iqa' al-firqa). ${ }^{142}$ Second, and perhaps most troubling, he stated that the power of talaq is not extended to a woman because her whims and desires overtake her (shahwatuha taghlibuha) and hence she may be hasty to pronounce a divorce when there is disagreement between the spouses. But men, he said, dominate their desires more than women, and so are less likely to hastily invoke the talaq power at the first sign of

137. Qur'an 65:1.

138. Al-Mawardi, supra n. 108, at 10:111.

139. Id. at I0;113.

140. Id.

141. Id. at 10:114, quoting Qur'an 2:228, which states in full:

Divorced women shall wait conceming themselves for three monthly periods. Nor is it lawfil for them to hide what God has created in their wombs. If they have faith in God and the Final Day. And their husbands have the better right to take them back in that period, if they wish for reconciliation. And women shall have rights similar to the rights against them, according to what is equitable. But men have a degree over them. And God is exalted and wise (emphasis added).

142. Id. a t10:114. 
discord. $^{143}$

Al-Mawardi's discussion is one example of a premodern juristic analysis that was utilized to distribute the right of talaq to men and not women. Al-Mawardi relied in part on his extra-textual understanding of not just the individual, but more specifically the character and other relative obligations of men and women, to detennine how a specific private right should be distributed. As we have seen above, the conception of the individual and his or her relationship to society was very much contested by jurists through the rights of God/rights of individuals heuristic, where they arguably relied on such conceptions to balance between public and private rights, and provide limited determinacy to their discretion over the law. But more than balancing between public and private rights, jurists like al-Mawardi seemed to be balancing interests within the realm of private rights alone. The case of talaq is an example of this apparent discretionary balancing. Here, preconceptions of the nature of men and women fuel a specific reading of relevant scriptural texts, and thereby justify a particular distribution of private rights between competing parties. Jurists like al-Mawardi were not just relying on scriptural text to assert a particular division of rights. They relied on extraneous circumstantial factors to inform how they read scripture and how they used their discretion to create a rights regime. ${ }^{144}$

If prior Islamic legal precedent is to have any force in the Shari'a arbitration panels in Ontario, the above rules of premodem divorce law may pose an interesting challenge to the arbitrators. Despite their unilateral power, men will have a financial incentive to seek the aid of the panel since a court-issued decree of divorce will prevent their wives from claiming that the marriage is still valid, and thereby stop them from demanding ongoing financial support. In other words, an arbitral decree enforced by Canadian courts will provide a means of both registering divorces, and granting legal clarity on the financial responsibilities of one party to the other. ${ }^{145}$ But just as importantly, how will the court treat

143. $k d$.

144. Notably, Muslim govermments such as Egypt have arguably adopted a similar conception of both men and women to justify their unequal distribution of divorce rights, despite the fact that their respective rights schemes contravene the express provisions of CEDAW, which many of them have ratified with reservations. For Egypt's reservation to Article 16 of CEDAW, which relies on a presumed Islamic distinction between men and women see Convention on the Elimination of All Forms of Discrimination against Women (available at http:/iuntreaty.un.org /ENGLISH/biblelenglishinternetbible/part/chapterIV/treaty10.asp (accessed Nov. 4, 2005)).

145. Many Muslim countries that apply Islamic marriage and divorce law have restricted a husband's unilateral right to divorce by requiring him to petition a court for divorce. Others such as Egypt require the husband to provide his wife a notarized document indicating that she is divorced. See Almad Na'im, supra n. 136, at 87-186. 
women's petitions for divorce? Will the panel distinguish between fault-based claims and no-fault based claims? Will women seeking a no-cause divorce before these panels be forced to give up financial claims against their husbands, and in a sense, purchase their freedom? If it requires this, the panel will discriminate between women seeking fault-based divorces, and those seeking no-fault divorces, and in a sense, penalize the latter for doing so. Furthennore, this procedure creates an incentive for husbands to act in bad faith toward their wives. Suppose a husband and wife are ill-matched, but the wife can allege no fault-based ground for divorce. The husband has an interest not to seek divorce on his own initiative, thereby forcing his wife to seek a no-cause divorce and renounce any financial claims upon her husband. How the arbitrators will resolve these very real public policy concerns will depend, in part, on whether they understand Islamic law as a fixed positivist system of law based on scripture and prior precedent, or take into account a heuristic like the rights of God/rights of individuals, which arguably empowers them justifiably and legitimately to use their discretion to continue debating over the construction of the law, and the distribution of rights under Islamic law pursuant to evolving conceptions of the individual, the social good, and the relationship between the two. 